\title{
Adıyaman ve Gaziantep İstasyonlarındaki Güneşlenme Şiddetinin Destek Vektör Makineleri ile Tahmini
}

\section{Estimation of Solar Radiation in Adıyaman and Gaziantep Stations Using Support Vector Machines}

\author{
Latif Doğan Dinsever ${ }^{*}$, Veysel Gümüş ${ }^{2}$, Oğuz Şimşek ${ }^{3}$, Yavuz Avşaroğlu ${ }^{4}$, Mehmet Kuş ${ }^{5}$ \\ Geliş / Received: 27/03/2021 \\ Revize / Revised: 10/08/2021 \\ Kabul / Accepted: 26/08/2021
}

\begin{abstract}
öz
Güneş enerjisi teknolojilerinin kullanımı, birçok ülkede enerji talebini karşılamak ve sürdürülebilir enerji kaynağı sağlamak amacıyla son yıllarda gelişerek artmaktadır. Bu teknolojilerin verimli kullanılabilmesi için, güneşlenme şiddeti verilerinin doğru bir şekilde belirlenmesi gerekmektedir, böylece yapılacak olan yatırımların verimliliği de önceden belirlenebilecektir. Güneş enerjisi ölçüm cihazlarının yetersizliğinin yanında var olan ekipmanların yenilenme veya onarım maliyetlerinden dolayı, literatürde meteorolojik istasyonlardan elde edilen verilerin girdi parametresi olarak kullanılması ve yapay zekâ yöntemleri ile güneşlenme şiddeti verilerinin hesaplanması yapılmaktadır. Bu çalışmada, Adıyaman ve Gaziantep istasyonlarına ait, sıcaklık, nem, ortalama basınç, rüzgâr, aylık açık gün sayısı ve takvim ayı gibi farklı girdi parametreleri kullanılarak, bu istasyonlara ait aylık ortalama güneşlenme şiddeti tahmin edilmeye çalışılmıştır. Aylık ortalama güneşlenme şiddetinin tahmin edilmesi için, destek vektör makineleri yönteminin üç farklı çekirdek fonksiyonu (Radyal, Lineer ve Polinom) kullanılmıştır. Ele alınan çekirdek fonksiyonlarının güneşlenme şiddetini tahmin etmedeki başarısında, belirlilik katsayısı $\left(\mathrm{R}^{2}\right)$, Karekök Ortalama Karesel Hata (KOKH), Ortalama Mutlak Yüzde Hata (OMYH), Nash-Sutcliffe verimlilik katsayısı (NSE) ve Yüzde Hata (PBIAS) parametreleri başarı kriteri olarak tercih edilmiştir. Çalışma sonucunda, destek vektör makinelerinin Radyal ve Polinom çekirdek fonksiyonlarının güneşlenme şiddetini belirlemede genel olarak başarılı sonuçlar verdiği görülmüştür. Ayrıca, girdi parametresi olarak ortalama sıcaklık ve ortalama basıncın kullanılmasının tahmin modellerinin performansını artırdığı belirlenmiştir.
\end{abstract}

Anahtar Kelimeler- Güneşlenme Şiddeti, Yapay Zekâ Yöntemleri, Destek Vektör Makineleri

\begin{abstract}
Using of solar energy technologies have been developing and increasing in many countries in recent years to meet the energy demand and to provide sustainable energy source. In order to use the developing technologies efficiently, it is necessary to obtain energy source data, and this will ensure that the investments made in this way are more effective. Due to the insufficiency of solar energy measurement devices and the replacement or repair costs of equipment, it is necessary to use the data obtained from meteorological stations as input parameters in the
\end{abstract}

\footnotetext{
1*Sorumlu yazar iletişim: latifddinsever@harran.edu.tr (https://orcid.org/0000-0001-8573-1539) İnşaat Mühendisliği, Mühendislik Fakültesi, Harran Üniversitesi, Şanlıurfa, Türkiye 2illetişim: gumus@harran.edu.tr (https://orcid.org/0000-0003-2321-9526) Inșaat Mühendisliği, Mühendislik Fakültesi, Harran Üniversitesi, Sanlıurfa, Türkiye 3̇letişim: oguzsimsek@harran.edu.tr (https://orcid.org/0000-0001-6324-0229) Inșaat Mühendisliği, Mühendislik Fakültesi, Harran Üniversitesi, Sanlıurfa, Türkiye 4İletişim: yavsaroglu@harran.edu.tr (https://orcid.org/ 0000-0003-0920-3202) Inşaat Mühendisliği, Mühendislik Fakültesi, Harran Üniversitesi, Şanlıurfa, Türkiye 5Illetişim: mehmetkus@harran.edu.tr (https://orcid.org/ 0000-0003-2215-9250) Elektrik Bölümü, Teknik Bilimler Meslek Yüksekokulu, Harran Üniversitesi, Şanlıurfa, Türkiye
} 
literature and to calculate the solar adiation data with artificial intelligence methods. In this study, the monthly mean solar radiations of Adiyaman and Gaziantep stations are predicted using different input parameters, such as temperature, humidity, mean pressure, wind, number of clear days in a month, and month number. Three different kernel functions (Gaussian, Linear and Polynomial) of support vector machine are used to estimate the average monthly solar radiation. Coefficient of Determination $\left(\mathrm{R}^{2}\right)$, Root Mean Square Error (RMSE) Mean Absolute Percentage Error (MAPE) Nash-Sutcliffe model efficiency coefficient (NSE) and Percent Bias (PBIAS) parameters are used to determine the performance of selected kernel functions. As a result of the study, it is seen that the Gaussian and Polynomial kernel functions of support vector machines generally show successful output to determine the solar radiation. In addition, it is determined that the models that used mean temperature and mean pressure as input parameters improve the estimation performance.

\section{Keywords- Solar Radiation, Artificial Intelligence Methods, Support Vector Machine}

\section{GİRIŞ}

Güneş enerjisi, dünyanın enerji ihtiyacının önemli bir bölümünü karşılayabilecek en umut verici yenilenebilir enerji kaynağıdır [1]. Yeryüzüne düşen güneş enerjisinin doğru bir şekilde gözlemi ve bu gözlem sonucunda elde edilen verilerin doğru bir şekilde tahmin edilmesi, bu enerjiden daha verimli yararlanmak için önemlidir. Yeryüzüne gelen güneşlenme şiddeti, birçok tarımsal ve meteorolojik uygulamanın yanında üretilecek ürünlerin türünü de doğrudan etkilemektedir [2]. Güneş enerjisinin temel ölçüm parametresi olan güneşlenme şiddetinin de ölçüldüğü meteoroloji gözlem istasyonlarında, geçmişte elektronik olmayan sensörler kullanılmakta iken ve bu sensörlerin sağladığı verilerin de genellikle düşük kaliteli olmasından dolayı [3] son yıllarda bu istasyonların yerine elektronik istasyonlar tercih edilmeye başlanmıştır. Ancak, bu durum neticesinde de nitelikli personel ihtiyacı ortaya çıkmış ve işletme maliyetlerinde artış meydana gelmiştir. Bu nedenlerden dolayı, uzun dönemli güneşlenme şiddeti verilerine erişmede sorunlar meydana gelmiştir. Bu sorunların üstesinden gelmek ve planlama amacıyla geçmiş yıllara ait güneşlenme şiddeti verilerine erişmek için, farklı yaklaşımlara dayalı tahmin modelleri geliştirilmiştir. Bu tahmin modelleri yapay sinir ağları, zaman serisi yöntemleri, fiziksel olarak ışınımsal aktarım modelleri ve stokastik hava yöntemleridir [4]. Bu modeller, genelde farklı verileri girdi parametresi olarak kullanarak güneşlenme şiddetini tahmin etmektedir. Meteorolojik verilere dayalı güneşlenme şiddetinin modellenmesi, dünyada en sık kullanılan yöntemlerin başında gelmektedir [5]. Meteorolojik verileri kullanan bu modellerde, güneşlenme şiddetini tahmin etmek için güneşlenme şiddetiyle ilişskili olan sıcaklık, bağıl nem, bulutluluk, güneşlenme süresi vb. parametrelerin girdi olarak kullanıldığı regresyon tekniklerinden yararlanılmaktadır. Özellikle, geçmiş yıllarda ölçümü yapılan istasyonlarda bulunan maksimum ve minimum sıcaklık verileri ile güneşlenme şiddeti arasındaki ilişkinin modellenmesi birçok araştırmacı tarafından yapılmıştır [6-8].

Araştırmacılar, son yıllarda güneşlenme şiddetinin tahmini için geleneksel regresyon tekniklerinin yanında, Yapay Sinir Ağları (YSA), Uyarlanabilir Nöro-Bulanık Çıkarım Sistemi (Adaptive Neuro Fuzzy Inferecen System-ANFIS), Genetik Programlama (GP) ve Destek Vektör Makinesi (Support Vector MachineSVM) gibi yapay zekâ tekniklerini oldukça sık kullanmaktadır [9]. Örneğin, Kuzey İspanya Alava'da yer alan Bask bölgesindeki dört adet meteoroloji istasyonuna ait 1999-2003 yılları arasındaki günlük maksimum ve minimum sıcaklık değerlerini kullanılarak güneşlenme şiddeti tahmin edilmiştir [10]. Güneşlenme şiddetinin tahmin edilmesi için Gen İfadesi Programlama (Gene Expression Programming-GEP) yöntemi kullanılmış ve bu modelle elde edilen sonuçlar diğer yapay zekâ yöntemleri (YSA, ANFIS) ve ampirik denklemlerin sonuçlarıyla karşılaştırılmıştır. Çalışma sonucunda, yapay zekâ yöntemlerinin güneşlenme şiddetini belirlemede daha başarılı olduğu, GEP yönteminin ise girdi ve çıktı parametreleri arasındaki ilişkiyi ANN ve ANFIS yöntemlerine kıyasla daha başarılı bir şekilde modellediği bildirilmiştir. Güneş ışınımı ve güneşlenme süresi arasında doğrusal bir ilişki sağlayan klasik Angström-Prescott denklemi kullanılarak güneşlenme şiddeti hesaplanmıştır [11]. Çalışmada, Türkiye'nin güneyinde bulunan illerinden Adana, Antakya ve Silifke'de güneş radyasyonu incelemesi için üç güneş ışınımı modeli (Angstrom-Prescott, bağımlılık ve ANFIS) kullanılmıştır. Üç farklı modelin sonuçları karşılaştırılmış ve karşılaştırma sonucunda, bağımlılık modelinin diğer yaklaşımlardan daha üstün olduğu görülmüştür. Antakya ilinin güneşlenme şiddetini tahmin etmek için 2000-2010 yılları arasındaki günlük güneşlenme süresi kayıtları kullanılmıştır [12]. Güneşlenme şiddetinin tahmin edilmesinde, klasik modele göre iyileştirme içeren lineer bir denklem ile geliştirilen yeni Angstrom denkleminin klasik Angstrom denklemine göre daha başarılı olduğu belirlenmiştir. Çalışma sonucunda önerilen yeni denklemle hem kısa hem de uzun dönemli 
tahminlerde klasik Angstrom yaklaşımının hata oranını oldukça düşürdüğü görülmüştür. Ayrıca, önerilen yeni denklemde bağımlılık katsayısı olarak ek iki yeni faktörün ilave geldiği belirtilmiştir. Türkiye'de bulunan ve veri kayıt aralığı en az 20 yıl olan toplam 163 istasyona ait meteorolojik verileri, güneşlenme şiddetini tahmin etmek amacıyla kullanılmıştır [13]. Girdi parametresi olarak takvim ayı, ortalama sıcaklık ve bağıl nem gibi parametreleri kullanarak, Çoklu Doğrusal Regresyon (ÇDR), YSA ve ANFIS yöntemleri ile ampirik yaklaşımların güneşlenme şiddetini tahmin etmedeki başarısı değerlendirilmiştir. Çalışma sonucunda, Türkiye’nin güneşlenme şiddetinin tahmini için kullanılan yöntemler arasında, YSA yönteminin ele alınan diğer yöntemlerden daha başarılı olduğu belirtilmiştir. Türkiye'deki farklı güneş enerjisi potansiyeline sahip bölgelerde bulunan Adana, Gaziantep ve Silifke olmak üzere üç güneş ışınlama sahası ele alınmıştır [14]. Güneşlenme enerjisi potansiyelinin tahmininde Harmonik ve klasik regresyon analizlerinin kombine edildiği bir model olan HarLin modeli kullanılmış ve bu modelin sonuçları ANFIS ve klasik regresyonun bir formu olan Angstrom-Prescott yaklaşımlarıyla karşılaştırılmıştır. Sonuç olarak yaklaşımlara ait sonuçların karşılaştırılmasından, ele alınan istasyonların güneşlenme enerji potansiyelinin belirlenmesinde HarLin modelinin kullanılan diğer modellerden daha iyi tahminde bulunduğu belirlenmiştir. Cezayir Ghardaïa'da sıcaklık, güneşlenme süresi, bulutluluk ve fark sıcaklık vb. meteorolojik parametreleri kullanılarak, SVM yöntemiyle günlük ve aylık güneşlenme şiddetini tahmin edilmiştir [15]. Çalışma sonucunda, SVM yöntemi ile güneşlenme şiddeti tahmininde, güneşlenme süresi ve sıcaklık parametrelerinin girdi olarak kullanıldığı modellerin diğer modellere kıyasla daha başarılı olduğu görülmüştür. Zimbabwe'deki güneşlenme şiddetinin tahmininde YSA yöntemi kullanılmıştır. Rakım, enlem, boylam gibi coğrafi verilerin yanı sıra, bağıl nem, basınç, ortalama sıcaklık gibi meteorolojik veriler de girdi parametresi olarak kullanılmıştır [16]. Ayrıca, netlik indeksinin (clearness index) güneşlenme şiddetinin tahmini üzerindeki etkisini de araştırmışlardır. Çalışma sonucunda, netlik indeksi ve sıcaklık parametrelerinin, güneşlenme şiddetinin tahmin edilmesinde kullanılan modellerin performansını, diğer parametrelere kıyasla daha çok arttırdığı bildirilmiştir. Suudi Arabistan'ın güneybatısında bulunan Sharurha'da, SVM yöntemi ile güneşlenme şiddetini tahmin etmek için kurulan modelin, 1998-2002 yılları arasındaki bağıl nem ve sıcaklık parametrelerinden oluşan 1600 günlük veri setini dört farklı kombinasyonda eğitim sürecinde, 212 günlük veri setini ise test sürecinde kullanılmıştır[17]. Elde edilen sonuçlar, SVM modelinin güneşlenme şiddetini tahmin etmede oldukça başarılı olduğunu göstermiştir. Küresel güneşlenme şiddetinin tahmini için Mısır'ın 10 farklı noktasında ölçülmüş olan 20 y1llık sıcaklık verileri kullanılmıştır [18]. Toplam 20 farklı model oluşturulmuş ve bu modellerin performans değerlendirmesi için karekök ortalama karesel hata $(\mathrm{KOKH})$, ortalama mutlak yüzde hata (OMYH) ve belirlilik katsayısı $\left(\mathrm{R}^{2}\right)$ parametreleri kullanılmıştır. Çalışma sonucunda, güneşlenme şiddetinin ölçümünde ekipman bulunmayan, sıcaklığa dayalı doğru ve güvenilir bir model ile güneşlenme şiddeti hesaplanmıştır. 2004 yılı süresince Cezayir'de bulunan 13 istasyona ait enlem, ortalama sıcaklık, bağıl nem, Linke bulanıklık faktörü ve Angstrom katsayısı verilerini kullanılarak, YSA yöntemi ile küresel güneşlenme şiddeti tahmin edilmiştir [19]. Çalışma sonucunda, önerilen modelin Cezayir'in kırsal bölgelerindeki güneş ışınımları potansiyelini belirlemek için kullanılabileceği belirtilmiştir. Çin'de bulunan 21 adet istasyona ait meteorolojik veriler (güneşlenme süresi, basınç, sıcaklık ve bağıl nem) kullanılarak, ANFIS ve bu yöntemin iki adet optimize edilmiş hali olan Izgara Bölmeli (ANFIS-GP), Çıkarımlı Kümelemeli (ANFIS-SC) ve M5Tree teknikleri ile günlük güneşlenme şiddeti tahmin edilmiştir [20]. Kullanılan modellerin başarısı KOKH, $\mathrm{R}^{2}$ ve ortalama mutlak hata (OMH) kriterleriyle değerlendirilmiştir. Sonuç olarak, ANFIS yöntemi ile elde edilen sonuçların başarısının ele alınan diğer yöntemlerden biraz daha iyi olduğu görülmüştür. Beş farklı ülke için (Mısır, Ürdün, Tunus, Cezayir ve Fas) Karar Ağacı (Decision Tree-DT) regresyon yöntemine ait farklı algoritmalar kullanılarak günlük ve saatlik zaman ölçeklerinde güneşlenme şiddeti tahmin edilmeye çalışılmıştır [21]. DT yönteminin, YSA ve SVM yöntemleri ile karşılaştırılması sonucunda, yöntemlerin güneşlenme şiddetini belirlemede benzer performanslar gösterdiği ve önerilen modelin güneşlenme şiddetini hesaplamada büyük potansiyele sahip olduğu belirlenmiştir. Tekirdağ, Sinop, Hakkâri, Afyon ve Ağrı illeri için SVR, YSA ve DT yöntemleri ile saatlik güneşlenme şiddeti değerleri tahmin edilmiştir [22]. KOKH ve $\mathrm{R}^{2}$ değerleri, kullanılan yöntemlerin başarısını belirlemede niceliksel başarı ölçütü olarak kullanılmıştır. Sonuç olarak, kullanılan yöntemlerin, güneşlenme şiddetini tahmin etmede kabul edilebilir düzeyde olduğunu ifade edilmiştir. Güneş enerjisi potansiyeli en yüksek olan Güneydoğu Anadolu bölgesinde bulunan Gaziantep ili için güneş enerjisi verimlilik haritası çok kıstasla karar verme yöntemlerinden biri olan Analitik Hiyerarşi Yöntemini (AHY) kullanılarak elde edilmiştir [23]. Çalışmanın sonucunda, Gaziantep ili arazilerinin güneş enerjisi potansiyelinin yaklaşık \%8'inin çok uygun olduğu, \%44'ünün ise uygun olduğu belirlenmiştir. Türkiye ve ABD olmak üzere iki farklı konumdaki rüzgâr hızı, sıcaklık ve bağıl nem meteorolojik parametrelerini kullanılarak altı farklı makine öğrenme modeli ile güneşlenme şiddeti tahmin edilmeye çalışılmıştır [24]. Çalışmada, Gradyan Artırma Ağacı (GBT), Çok Değişkenli Uyarlamalı Regresyon Eğrisi (MARS), Regresyon Ağacı (CART), YSA, ANFIS ve ANFIS'ten türetilmiş olan Ortalamalı Kümelenmiş ANFIS (ANFIS-FCM) ile Çıkarımlı Kümeleme (ANFIS-SC) yöntemleri kullanılmıştır. Modellerin performans 
sıralamasını belirlemek için başarı kriteri olarak KOKH, OMH, korelasyon katsayısı (R), ve Nash-Sutcliffe verimlilik katsayısı (NSE) kullanılmıştır. Çalışma sonucunda, iklim parametreleri girdi olarak kullanılarak güneşlenme şiddetini tahmin etmede kullanılan GBT modelinin diğer modellere kıyasla daha başarılı olduğu görülmüştür.

Geçmiş yıllarda yapılmış olan çalışmalar değerlendirildiğinde, bir bölgenin güneş enerjisi potansiyelini belirlemede oldukça önemli bir parametre olan güneşlenme şiddeti tahmininin yoğun bir şekilde çalışmalara konu olduğu görülmektedir Ayrıca, özellikle kısıtlı girdi parametrelerinin de değerlendirmeye alındığı farklı bölgelerde ve farklı yöntemlerle güneşlenme şiddetinin tahmin performansının belirlenmesine ihtiyaç duyulduğu anlaşılmaktadır. Bu amaçla, çalışma kapsamında, Türkiye için güneş enerjisi potansiyelinin yüksek olduğu Adıyaman ve Gaziantep illerine ait güneşlenme şiddeti değerlerinin tahmininde girdi parametresi olarak farklı meteorolojik verilerin kombinasyonları değerlendirilmiştir. Ayrıca, literatürde de verilmiş olan Destek Vektör Makinaları (SVM) yöntemlerinin tahmin performansı üzerinde etkisi olan çekirdek fonksiyonları da incelenmiştir. Bu amaçla, SVM yöntemindeki Radyal, Lineer ve Polinom çekirdek fonksiyonlarının güneşlenme şiddetini tahmin etmedeki başarısı detaylı bir şekilde ele alınmıştır.

\section{II. ÇALIŞMA ALANI VE VERÍLER}

Türkiye, konum olarak Avrupa ülkeleri içerisinde güneş enerjisi potansiyeli olarak oldukça iyi bir yerde bulunmaktadır (Şekil 1). Şekil 1'den, ülkemizin Akdeniz'e kıyısı bulunan ülkelerle benzer, Avrupa'da yer alan diğer ülkelerden ise genel olarak daha yüksek bir güneşlenme şiddeti dağılımı sergilediği görülmektedir. Türkiye, y1llık yaklaşık 190 TW/h güneş enerjisi potansiyeli ile İspanya'dan sonra Avrupa'da ikinci sırada yer almaktadır. [25]. Türkiye'nin güneşlenme şiddetinin mekânsal dağılımı ise daha detaylı olarak Şekil 2'de verilmiştir. Buna göre, Türkiye'nin kuzey ve batı kesimlerindeki güneşlenme şiddetinin, Türkiye'nin güney ve doğu bölgelerine göre nispeten daha az olduğu görülmektedir. Bu çalışma kapsamında ele alınan Gaziantep ve Adıyaman istasyonlarına ait güneşlenme şiddeti değerleri de $1600-1750 \mathrm{kWh} / \mathrm{m}^{2}$-yıl aralığındadır. Ele alınan17261 numaralı Gaziantep (37.0585 K, 37.3510 D) ve 17265 numaralı Adıyaman (37.7553 K, 38.2775 D) illerinde bulunan ve konumları Şekil 2'de verilen istasyonlara ait ortalama sıcaklık (OS), maksimum sıcaklık (MaS), minimum sıcaklık (MiS), bağıl nem (NEM), ortalama basınç (OB), rüzgâr hızı (RH), aylık açık gün sayısı (AAGS) ve takvim ayı verileri, güneşlenme şiddeti değerinin tahmin etmek amacıyla girdi parametresi olarak kullanılmıştır. Girdi parametreleri ve tahmini yapılan güneşlenme şiddetine ait ortalama, maksimum, minimum, standart sapma, çarpıklık değerleri, girdi parametrelerinin GS ile olan korelasyonu ile eksik veri yüzde değerleri Tablo 1'de verilmiştir. Tablodan, Adıyaman istasyonuna ait OS, MiS, MaS, OB ve RH değerlerinin ortalamaları Gaziantep istasyonuna ait değerlerden yüksek olduğu, AAGS ve güneşlenme şiddeti (GS) değerlerinde ise tam tersi bir durum görülmektedir. Adıyaman istasyonunda elde edilen sıcaklık verilerine ait ortalama değerlerin Gaziantep istasyonuna ait değerlerden büyük olmasına rağmen, güneşlenme şiddetinde tam tersi bir durum meydana gelmesinin nedeni, açık gün sayısı, güneşlenme süresi ya da istasyonun enlem ve boylamı gibi farklı parametrelerin, güneşlenme şiddeti verilerini etkilediği şeklinde değerlendirilmektedir. Bunun yanında, tahmin edilmeye çalışılan parametre olan GS ile girdi olarak kullanılan farklı sıcaklık (OS, MaS ve MiS) parametreleri ve OB parametresi arasındaki korelasyon katsayılarının her iki istasyonda da diğer parametrelere ait korelasyon katsayısından büyük olduğu, RH ve $\mathrm{OB}$ parametrelerinin tahmin parametresiyle arasındaki korelasyon katsayılarından bu girdi parametreleriyle GS arasında ters korelasyonun bulunduğu görülmektedir. Ayrıca, kullanılan verilere ait eksik veri yüzdesi maksimum \%1.7 olarak belirlenmiş ve bu eksik veriler komşu istasyon verileri kullanılarak lineer regresyon yöntemi ile tamamlanmıştır. Ayrıca, veri setlerindeki 1.5 IQR (Çeyreklik Açıklığı)'dan büyük değerler aykırı olarak değerlendirilerek, silinmiş ve eksik veri olarak değerlendirilmiştir. 


\begin{tabular}{|c|c|c|}
\hline & $\begin{array}{l}\text { BŞEÜ Fen Bilimleri Dergisi } \\
8(2), 753-769,2021\end{array}$ & $\begin{array}{r}\text { BSEU Journal of Science } \\
\text { https://doi.org/10.35193/bseufbd.904393 }\end{array}$ \\
\hline $\begin{array}{l}\text { BiLECIKSEYYH EDEBALI } \\
\text { UNIVERSITESI }\end{array}$ & & 2458-7575 (https://dergipark.org.tr/tr/pub/bseufbd) \\
\hline
\end{tabular}

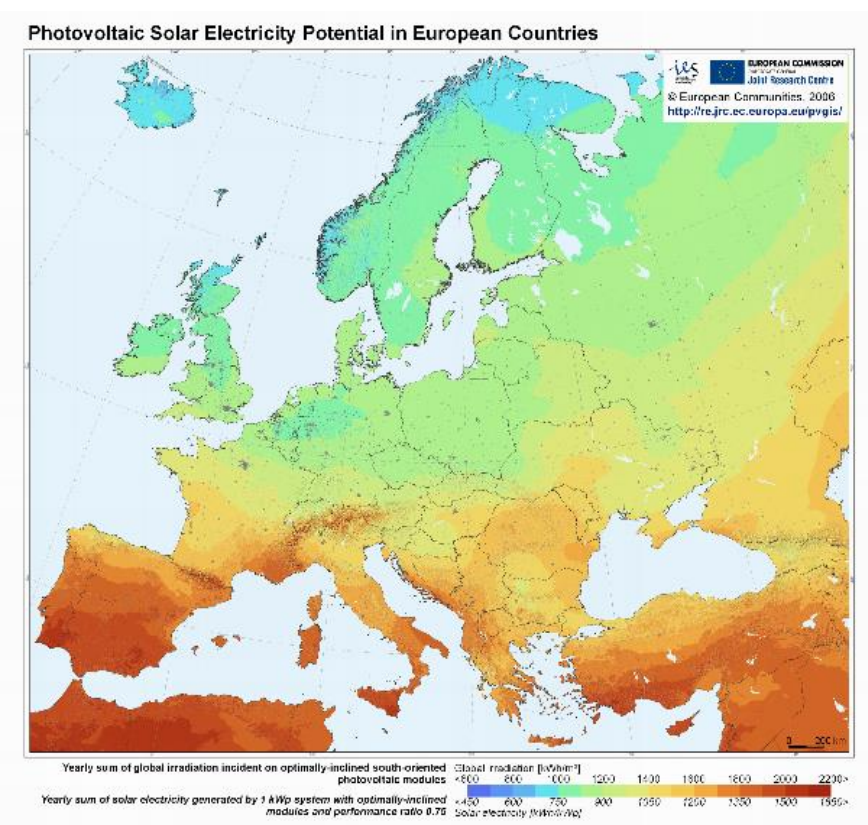

Şekil 1. Avrupa'nın güneş enerjisi potansiyelinin mekansal dağılımı [26]

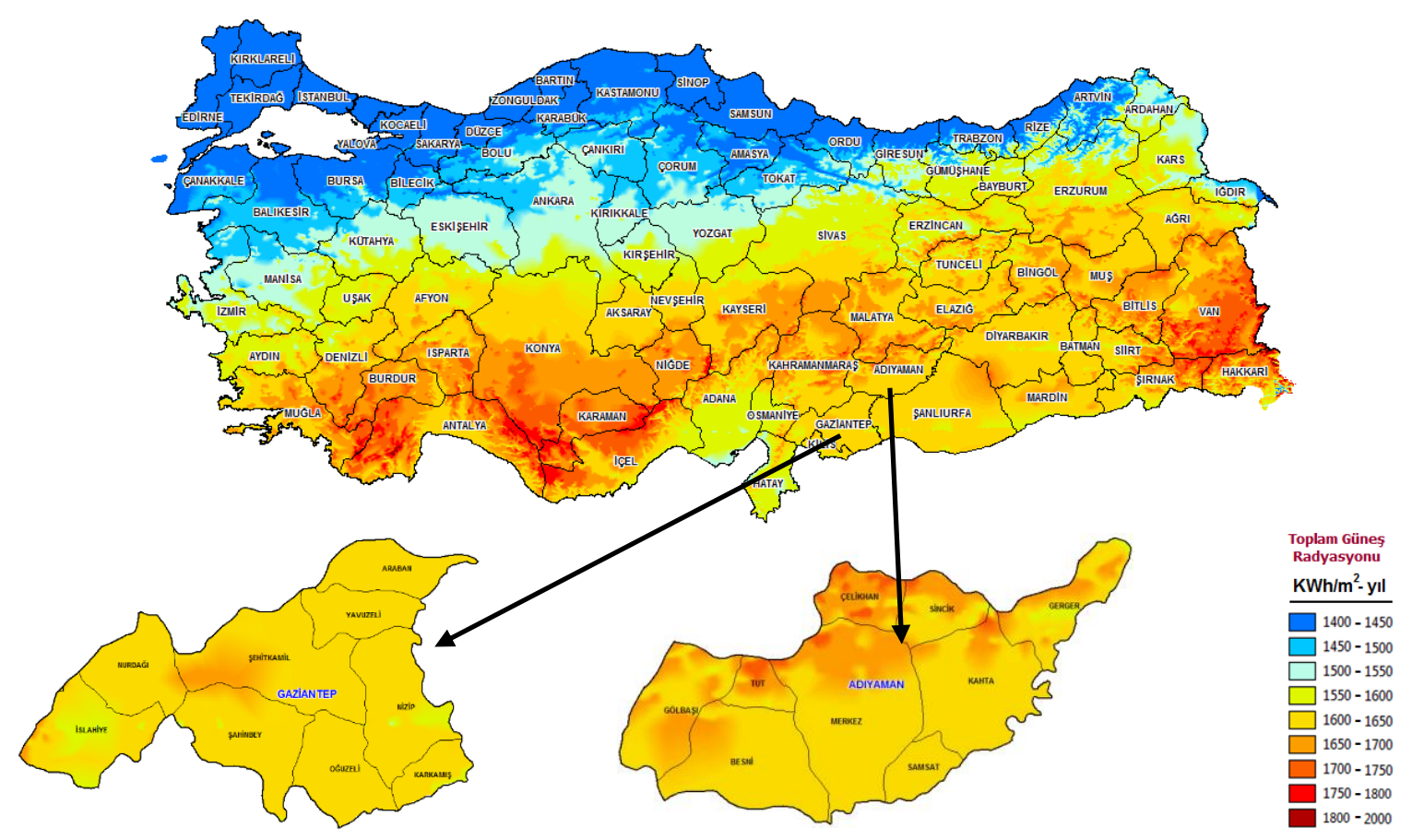

Şekil 2. Türkiye, Gaziantep ve Adıyaman'a ait güneşlenme şiddetinin mekânsal dağılımı[27] 
Tablo 1. Kullanılan meteorolojik parametrelerin istatistikleri

\begin{tabular}{|c|c|c|c|c|c|c|c|c|}
\hline Parametre & İstasyon & Ortalama & Maksimum & Minimum & Standart Sapma & Çarpıklık & Korelasyon & $\begin{array}{l}\text { Eksik } \\
\text { Veri }\end{array}$ \\
\hline \multirow{2}{*}{$\begin{array}{l}\mathrm{OS} \\
\left({ }^{\circ} \mathrm{C}\right)\end{array}$} & Adiyaman & 17.16 & 33.50 & -0.10 & 9.45 & 0.064 & 0.846 & 0 \\
\hline & Gaziantep & 15.20 & 31.50 & -2.50 & 8.97 & 0.042 & 0.864 & 0 \\
\hline \multirow{2}{*}{$\begin{array}{l}\mathrm{MiS} \\
\left({ }^{\circ} \mathrm{C}\right)\end{array}$} & Adiyaman & 11.85 & 25.60 & -4.30 & 7.95 & 0.072 & 0.827 & 0 \\
\hline & Gaziantep & 9.40 & 24.10 & -9.00 & 7.85 & 0.111 & 0.840 & 0 \\
\hline \multirow{2}{*}{$\begin{array}{l}\mathrm{MaS} \\
\left({ }^{\circ} \mathrm{C}\right)\end{array}$} & Adiyaman & 22.89 & 41.60 & 3.90 & 10.52 & 0.032 & 0.847 & 0 \\
\hline & Gaziantep & 21.75 & 39.80 & 3.00 & 10.01 & -0.025 & 0.866 & 0 \\
\hline \multirow{2}{*}{$\begin{array}{c}\mathrm{OB} \\
(\mathrm{hPa})\end{array}$} & Adiyaman & 935.81 & 944.20 & 920.50 & 4.49 & -0.317 & -0.856 & 0 \\
\hline & Gaziantep & 916.15 & 926.60 & 907.70 & 3.80 & -0.036 & -0.831 & 0 \\
\hline \multirow{2}{*}{$\begin{array}{c}\text { NEM } \\
(\%)\end{array}$} & Adiyaman & 49.16 & 81.00 & 13.80 & 16.01 & -0.004 & -0.808 & 0 \\
\hline & Gaziantep & 61.25 & 89.60 & 27.80 & 13.25 & -0.197 & -0.772 & 0 \\
\hline \multirow{2}{*}{$\begin{array}{l}\text { AAGS } \\
\text { (gün) }\end{array}$} & Adiyaman & 15.97 & 31.00 & 2.00 & 8.56 & 0.298 & 0.625 & $\% 0.4$ \\
\hline & Gaziantep & 17.21 & 31.00 & 1.00 & 8.74 & 0.103 & 0.673 & 0 \\
\hline \multirow{2}{*}{$\begin{array}{c}\mathrm{RH} \\
(\mathrm{m} / \mathrm{s})\end{array}$} & Adiyaman & 2.07 & 4.70 & 0.70 & 0.56 & 0.666 & 0.411 & $\% 1.4$ \\
\hline & Gaziantep & 1.52 & 4.20 & 0.40 & 0.72 & 1.116 & 0.508 & $\% 1.4$ \\
\hline \multirow{2}{*}{$\begin{array}{c}\text { GS } \\
\left(\mathrm{cal} / \mathrm{cm}^{2} / \text { gün}\right)\end{array}$} & Adiyaman & 324.09 & 637.50 & 83.10 & 134.86 & 0.070 & 1.000 & $\% 1.7$ \\
\hline & Gaziantep & 341.07 & 618.70 & 75.70 & 144.62 & 0.013 & 1.000 & $\% 0.4$ \\
\hline
\end{tabular}

\section{YÖNTEM}

\section{A. Destek Vektör Makineleri (Support Vector Machine-SVM)}

Vapnik [28] tarafindan önerilen Destek Vektör Makineleri (Support Vector Machine-SVM), yapısal risk optimizasyonu ve makine öğrenme teorilerinin hem sınıflandırma hem de regresyon amacıyla kullanıldığı bir yöntemdir. SVM yöntemi, temelde makine öğrenmelerinin bir alt alanı olarak ortaya çıkmaktadır.Bu yöntem, istatistiksel öğrenme teorisindeki sağlam matematiksel temellerine ek olarak, çok sayıda mühendislik uygulamasında oldukça iyi performans göstermiştir. Öncelikli olarak sınıflandırma problemlerini çözmek için geliştirilen SVM yöntemi, daha sonrasında destek vektör regresyonu (Support Vector Regression-SVR) olarak adlandırılan regresyon problemlerinde de başarıyla uygulanmıştır [29-36].

SVM algoritmasındaki yaklaşık fonksiyon Denklem 1'de verilmiştir.

$$
f(x)=\omega \cdot \varphi(x)+b
$$

burada; $\varphi(x)$, x giriş vektöründen dönüştürülmüş daha yüksek boyutlu özellik uzayını, $\omega$ ve $b$ ise sırasıyla ağırlık vektörü ve bias terimini ifade etmektedir. $b$ ve $\omega$ değerleri minimize edilerek elde edilen risk fonksiyonu Denklem 2'de verilmiştir.

$$
R(C)=C \sum_{i}^{N} L_{\varepsilon}\left(f\left(x_{i}\right), y_{i}\right) \frac{1}{2}\|\omega\|^{2}
$$

burada, $\frac{1}{2}\|\omega\|^{2}$ terimi SVM'nin düzenleme terimini, C ise optimizasyondaki hata oranını gösteren dengeleyici parametresini temsil etmektedir.

Vapnik doğrusal fonksiyonu ile klasik regresyon fonksiyonları arasındaki en önemli farklılık Novell kayıp fonksiyonu $(L \varepsilon)$ 'dur (Denklem 3). Beklenmedik aykırı değerleri önlemek için pozitif değerlere sahip olan iki adet değişken $\left(\xi\right.$ ve $\left.\xi^{*}\right)$ tanımlanmıştır. Optimizasyon problemlerini çözmek için Lagrange çarpanları $\left(a, a^{*}\right)$ eklenmiştir.

$$
L \varepsilon\left(f\left(x_{i}\right), y_{i}\right)=\left\{\begin{array}{l}
\left|f\left(x_{i}\right)-y_{i}\right| \leq \varepsilon=0 \\
|f(x)-y|-\varepsilon \neq 0
\end{array}\right\}
$$

Lagrange çarpanlarının hesaplanmasından sonra Denklem 1'in son hali Denklem 4'teki gibi olmaktadır:

$$
f\left(x, a, a^{*}\right)=\sum_{i=1}^{n}\left(a_{i}-a_{i}^{*}\right) K\left(x_{i}, x_{j}\right)+b
$$


burada $K\left(x_{i}, x_{j}\right)$ çekirdek fonksiyonu olarak adlandırılmakta olup $K\left(x_{i}, x_{j}\right)=\varphi\left(x_{i}\right) \varphi\left(x_{j}\right)$ olarak hesaplanmaktadır. $\mathrm{Bu}$ işlemlerin ardından, SVM ana fonksiyonu:

$$
y=f(x)=\left\{\sum_{i=1}^{N} a_{i} K\left(x_{i}, x\right)\right\}-b
$$

şekline dönüşmektedir. Burada, $K$ çekirdek fonksiyonunu, $a_{i}$ ve $b$ SVM’ye ait parametreleri, N eğitim verilerinin sayısını, $x_{i}$ eğitim sürecinde kullanılan vektörleri ve $x$ ise bağımsız vektörü temsil etmektedir. Uygun bir çekirdek fonksiyonunun seçimi, kullanılacak verilerden daha doğru sonuçlar elde etme açısından önemlidir [37]. Bu çalışmada kullanılan üç temel çekirdek fonksiyonu Tablo 2'de verilmiştir. Tablo 2'de bulunan $\mathrm{x}_{\mathrm{i}}$ ve $\mathrm{x}_{\mathrm{j}}$ destek vektörlerini, $d, r$, ve $\gamma$ ise çekirdek parametrelerini ifade etmektedir. Analizler Matlab ile hazırlanmış kodlar ile yapılmış olup, SVM'ye ait çekirdek fonksiyonu içerisindeki parametreler Bayesian optimizasyon algoritması [38] ile belirlenmiştir.

Tablo 2.Çekirdek fonksiyonları

\begin{tabular}{l|l}
\hline Radyal Tabanlı (Gauss) Fonksiyon (SVM $\mathrm{RTF})$ & $K\left(x_{i}-x_{j}\right)=\exp \left(-\gamma\left\|x_{i}-x_{j}\right\|^{2}\right), \quad \gamma>0$ \\
\hline Polinom Fonksiyon $\left(\mathrm{SVM}_{\mathrm{PF}}\right)$ & $K\left(x_{i}-x_{j}\right)=\left(\gamma x_{i} \cdot x_{j}+r\right)^{d}, \quad \gamma>0$ \\
\hline Lineer (doğrusal) Fonksiyon $\left(\mathrm{SVM}_{\mathrm{LF}}\right)$ & $K\left(x_{i}-x_{j}\right)=x_{i} \cdot x_{j}$ \\
\hline
\end{tabular}

\section{BULGULAR}

SVM'nin farklı çekirdek fonksiyonları ile güneşlenme şiddetinin tahmin edilmesi için Tablo 3'te verilmiş olan altı farklı girdi kombinasyon durumu değerlendirilmiştir. Tabloda yer alan GS, aylık ortalama güneşlenme şiddetini; AY, takvim ayını (ocak için 1, şubat için 2 vb.); OS, aylık ortalama sıcaklı̆̆ı; MiS, aylık ortalama günlük minimum sıcaklığı; MaS, aylık ortalama günlük maksimum sıcaklığı; OB, ortalama basıncı; NEM, aylık ortalama nemi; AAGS, aylık açık gün sayısını ve RH, ise aylık ortalama rüzgâr hızı parametrelerini temsil etmektedir. Girdi parametreleri kombinasyonlarının belirlenmesinde, tarihsel meteorolojik parametrelerin genel olarak bulunma durumu dikkate alınmıştır. Örneğin, ilk durum olan D01'de takvim ayı sayısı ve ortalama sıcaklık parametreleri değerlendirmeye alınmış ve böylece güneşlenme şiddetini uzun yıllar öncesine kadar tahmin etme durumu meydana gelmiştir. Bunun yanında, literatürde güneşlenme şiddeti üzerine etkisi oldukça yüksek olduğu bildirilen güneşlenme süresi verisi, tarihsel olarak sürekli kayıtları bulunmadığından girdi parametresi olarak değerlendirmeye alınamamıştır.

Tablo 3. Ele alınan girdi kombinasyonları

\begin{tabular}{c|l|c}
\hline Durum & \multicolumn{1}{|c}{ Girdi Parametreleri } & \multicolumn{1}{|c}{ Çıtı Parametresi } \\
\hline D01 & AY, OS & GS \\
\hline D02 & AY, OS, MiS, MaS & GS \\
\hline D03 & AY, OS, MiS, MaS, OB & GS \\
\hline D04 & AY, OS, MiS, MaS, OB, NEM & GS \\
\hline D05 & AY, OS, MiS, MaS, OB, NEM, AAGS & GS \\
\hline D06 & AY, OS, MiS, MaS, OB, NEM, AAGS, RH & GS \\
\hline
\end{tabular}

Ayrıca, aylık güneşlenme şiddetini tahmin etmek amacıyla kullanılan modellerin başarısını değerlendirmek için belirlilik katsayısı $\left(\mathrm{R}^{2}\right)$, karekök ortalama karesel hata $(\mathrm{KOKH})$, ortalama mutlak yüzde hata (OMYH), Nash-Sutcliffe katsayısı (NSE) ve yanlılık yüzdesi (PBIAS) değerleri kullanılmıştır. R ${ }^{2}$, KOKH, OMYH, NSE ve PBIAS değerleri sırasıyla Denklem 6, 7, 8, 9 ve 10'da verildiği gibi hesaplanmıştır.

$$
\mathrm{R}^{2}=\frac{\sum_{n=1}^{N}\left(G S_{\text {gözlem }}-G S_{\text {ortalama }}\right)^{2}-\sum_{n=1}^{N}\left(G S_{\text {gözlem }}-G S_{\text {tah min }}\right)^{2}}{\sum_{n=1}^{N}\left(G S_{\text {gözlem }}-G S_{\text {ortalama }}\right)^{2}}
$$




$$
\begin{aligned}
& \mathrm{KOKH}=\sqrt{\frac{1}{N} \sum_{n=1}^{N}\left(G S_{\text {gözlem }}-G S_{\text {tahmin }}\right)^{2}} \\
& \mathrm{OMYH}=\frac{1}{N} \sum_{n=1}^{N}\left|G S_{g \ddot{z} \text { lem }}-G S_{\text {tahmin }}\right| \\
& \mathrm{NSE}=1-\left[\frac{\sum_{n=1}^{N}\left(G S_{\text {gözlem }}-G S_{\text {tahmin }}\right)^{2}}{\sum_{n=1}^{N}\left(G S_{\text {gözlem }}-G S_{\text {ortalama }}\right)^{2}}\right] \\
& \mathrm{PBIAS}=100 \frac{\sum_{n=1}^{N}\left(G S_{\text {gözlem }}-G S_{\text {tahmin }}\right)}{\sum_{n=1}^{N} G S_{\text {gözlem }}}
\end{aligned}
$$

Denklemlerde bulunan N, toplam veri sayısını; $G S_{\text {gözlem }}$, ölçülen güneşlenme şiddetini; $G S_{\text {ortalama }}$, ölçülen güneşlenme şiddeti değerlerinin ortalamasını; $G S_{\text {tahmin }}$ ise model sonucunda elde edilen güneşlenme şiddetini temsil etmektedir.

Modelleri başarılı olarak değerlendirebilmek için, $\mathrm{R}^{2}$ değerlerinin 1'e, KOKH ve OMYH değerlerinin ise 0'a yakın olması beklenmektedir. Ayrıca, NSE değerlerinin 0.75 ile 1 arasında bulunduğu durumlar modelin başarılı olduğunu, $0.5^{\prime}$ ten küçük olduğu durumlar ise model başarısının yetersiz kaldığını göstermektedir. PBIAS değerlerinin 0'a yakın olması model başarısının yüksek olduğunu ifade etmektedir. PBIAS'ın negatif olması gerçek değerlerin tahmin edilen değerlerden küçük olduğunu, pozitif olması ise büyük olduğunu göstermektedir [39].

\section{A. Lineer Çekirdek Fonksiyonu (SVM $\left.M_{L F}\right)$ Sonuçlart}

Farklı girdi parametreleri kullanılarak Gaziantep ve Adıyaman istasyonlarına ait güneşlenme şiddetinin $\mathrm{SVM}_{\mathrm{LF}}$ ile tahmin edilmesiyle elde edilen sonuçlar Tablo 4'te verilmiştir. Çalışmada, modellerin başarısının değerlendirilmesinde test süreci dikkate alınmıştır. Eğitim sürecinde Gaziantep istasyonunda D05 modeli en başarılı tahminde bulunurken, Adıyaman istasyonunda D06 modelinde en başarılı tahmin elde edilmiştir. Yapılan modelleme sonucunda, test sürecinde $\mathrm{SVM}_{\mathrm{LF}}$ yöntemi ile elde edilmiş olan $\mathrm{R}^{2}$ değerlerinin çoğunlukla 0.9 civarında olduğu görülmektedir. Her iki istasyonda da girdi parametresi olarak ortalama basıncın eklendiği, D03D06 modellerindeki başarının sadece sıcaklık parametrelerinin dikkate alındığı D01 ve D02 modellerine göre nispeten arttığı görülmektedir. $\mathrm{SVM}_{\mathrm{LF}}$ yöntemi ile elde edilmiş olan en başarılı modeller ise test sürecindeki $\mathrm{R}^{2}$, KOKH, OMYH ve NSE değerlerine göre Gaziantep istasyonu için D03, Adıyaman istasyonu için ise D05 olduğu belirlenmiş̧tir. PBIAS değerlerine göre ise, Gaziantep istasyonunda genel olarak tahmin edilen değerler gerçek değerlerden büyük olurken, Adıyaman istasyonunda ise tahmin edilen değerler gerçek değerlerden küçük olmuştur. 


\begin{tabular}{|c|c|c|}
\hline & $\begin{array}{l}\text { BŞEÜ Fen Bilimleri Dergisi } \\
8(2), 753-769,2021\end{array}$ & $\begin{array}{r}\text { BSEU Journal of Science } \\
\text { https://doi.org/10.35193/bseufbd.904393 }\end{array}$ \\
\hline $\begin{array}{l}\text { BILECIK SEYH EDEBALI } \\
\text { UN IVERSITESI }\end{array}$ & & 2458-7575 (https://dergipark.org.tr/tr/pub/bseufbd) \\
\hline
\end{tabular}

Tablo 4. $\mathrm{SVM}_{\mathrm{LF}}$ ile elde edilen eğitim ve test sonuçları

\begin{tabular}{|c|c|c|c|c|c|c|c|c|c|c|c|}
\hline \multirow{2}{*}{ İstasyon } & \multirow{2}{*}{$\begin{array}{c}\text { Durum } \\
\text { No }\end{array}$} & \multicolumn{5}{|c|}{ EĞїTіM } & \multicolumn{5}{|c|}{ TEST } \\
\hline & & $\mathbf{R}^{2}$ & KOKH & OMYH & NSE & PBIAS & $\mathbf{R}^{2}$ & KOKH & OMYH & NSE & PBIAS \\
\hline \multirow{6}{*}{ 总完 } & D01 & 0.8531 & 56.31 & 16.96 & 0.8499 & -0.3744 & 0.8835 & 77.04 & 27.77 & 0.6939 & -18.4492 \\
\hline & D02 & 0.8785 & 51.16 & 15.00 & 0.8783 & -0.5450 & 0.9037 & 62.30 & 21.71 & 0.7893 & -14.5038 \\
\hline & D03 & 0.9089 & 44.34 & 11.72 & 0.9086 & 0.6965 & 0.9047 & 47.63 & 15.47 & 0.8769 & -5.5116 \\
\hline & D04 & 0.9077 & 45.04 & 10.99 & 0.9057 & 1.5782 & 0.8887 & 47.76 & 15.59 & 0.8762 & -3.9396 \\
\hline & D05 & 0.9109 & 43.81 & 11.20 & 0.9108 & 0.3343 & 0.9017 & 47.98 & 15.91 & 0.8751 & -5.8300 \\
\hline & D06 & 0.9107 & 43.84 & 11.22 & 0.9107 & 0.2008 & 0.8975 & 47.70 & 15.51 & 0.8765 & -5.0983 \\
\hline \multirow{6}{*}{ 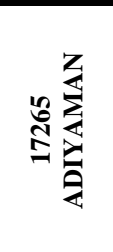 } & D01 & 0.8301 & 52.39 & 17.40 & 0.8276 & -0.0740 & 0.8262 & 73.95 & 17.42 & 0.7533 & 8.6743 \\
\hline & D02 & 0.8699 & 45.54 & 14.20 & 0.8697 & 0.3381 & 0.8792 & 68.75 & 16.03 & 0.7868 & 10.4179 \\
\hline & D03 & 0.8846 & 42.86 & 12.53 & 0.8846 & 0.2046 & 0.8928 & 63.77 & 14.46 & 0.8165 & 9.2824 \\
\hline & D04 & 0.8845 & 43.12 & 12.20 & 0.8831 & 1.0858 & 0.8962 & 66.43 & 14.63 & 0.8009 & 10.0808 \\
\hline & D05 & 0.8979 & 40.38 & 11.82 & 0.8976 & 0.5343 & 0.9153 & 59.22 & 13.27 & 0.8417 & 7.7923 \\
\hline & D06 & 0.9042 & 39.24 & 11.48 & 0.9032 & 0.8470 & 0.9050 & 76.73 & 16.61 & 0.7344 & 14.8126 \\
\hline
\end{tabular}

Oluşturulan bu modeller ile test sürecine ait Taylor diyagramları [40], Şekil 3’te verilmiştir. Taylor diyagramları, tahmin modelinin gerçek değerlere göre değerlendirilmesinde üç farklı kriteri kullanma imkanı tanımaktadır. Bunlar, korelasyon katsayısı (R), standart sapma ve detayları Taylor [40] tarafından verilmiş olan merkezi Denklem 11 kullanılarak hesaplanan Karekök Ortalama Karesel Fark (KOKF) parametreleridir.

$$
\mathrm{KOKF}=\left(\frac{1}{N} \sum_{n=1}^{N}\left[\left(G S_{\text {gözlem }}-\overline{G S}_{\text {gözlem }}\right)-\left(G S_{\text {tahmin }}-\overline{G S}_{\text {tahmin }}\right)\right]^{2}\right)^{1 / 2}
$$

$\mathrm{Bu}$ diyagramlarda, ölçüm verilerine (grafikte siyah nokta olarak gösterilen) ait değerlere yakınsama, model performansının yüksek olduğu anlamına gelmekte ve diyagramlardan Gaziantep istasyonu için D03, Adıyaman istasyonu için ise D05'in en başarılı modeller olduğu anlaşılmaktadır. Gaziantep istasyonunda oluşturulan modellerin birbirine çok yakın sonuçlar verdiği, Adıyaman istasyonunda ise D01 modelinin diğer modellere kıyasla korelasyon katsayısının daha küçük olduğu görülmektedir. Ayrıca, Gaziantep istasyonunda kullanılan modellere ait standart sapma değerlerinin, Adıyaman istasyonuna ait değerlerden daha büyük olduğu ve her iki istasyona ait KOKF değerlerinin incelenmesinden Gaziantep istasyonunda tüm modellerde KOKF değerlerinin 50'den küçük olduğu görülürken, Adıyaman istasyonunda bu değerlerin 50'den büyük olduğu görülmektedir.
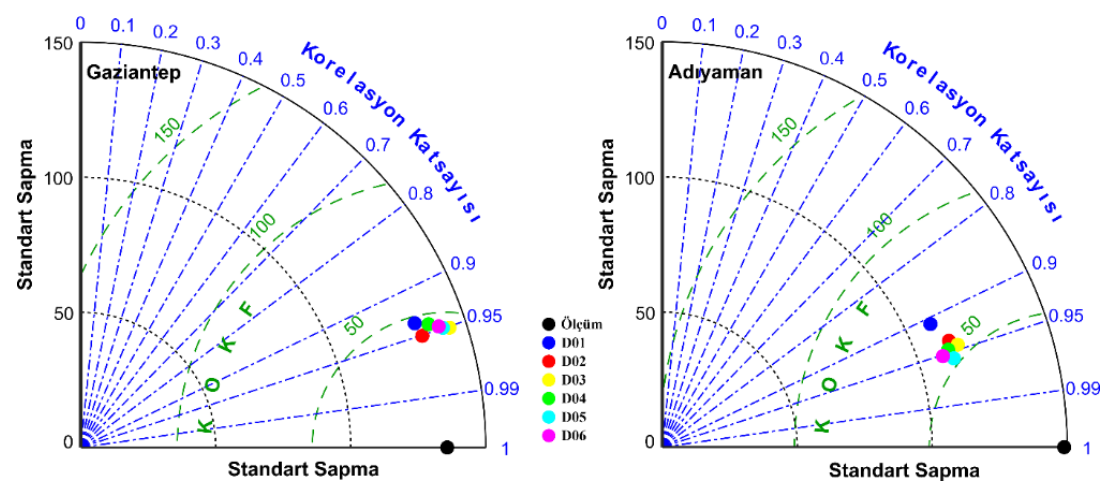

Şekil 3. $\mathrm{SVM}_{\mathrm{LF}}$ ile elde edilen Taylor diyagramları

D03 ve D05'e ait eğitim ve test süreçlerindeki ölçülen ve tahmin edilen güneşlenme şiddeti değerlerinin zamansal dağılım ve saçılım grafikleri Gaziantep istasyonu için Şekil 4'te, Adıyaman istasyonu için ise Şekil 5'te verilmiştir. Şekil 4 değerlendirildiğinde, Gaziantep istasyonu için eğitim sürecinde, 1981-1989 yılları arasında modelin $500 \mathrm{cal} / \mathrm{cm}^{2}$ 'den büyük değerleri tahmin etmede genel olarak çok başarılı olamadığı, ancak geri kalan zamanlarda başarılı olduğu görülmektedir. Test sürecinde ise eğitim sürecine benzer şekilde $500 \mathrm{cal} / \mathrm{cm}^{2} \mathrm{civarında}$ olan değerleri tahmin etme başarısının diğer değerleri tahmin etme başarısına kıyasla nispeten az olduğu görülmüştür. Şekil 5'te verilen Adıyaman istasyonuna ait sonuçlardan ise, eğitim sürecinde başarılı sonuçlar elde 


\begin{tabular}{|c|c|c|}
\hline & $\begin{array}{l}\text { BŞEÜ Fen Bilimleri Dergisi } \\
8(2), 753-769,2021\end{array}$ & $\begin{array}{r}\text { BSEU Journal of Science } \\
\text { https://doi.org/10.35193/bseufbd.904393 }\end{array}$ \\
\hline $\begin{array}{l}\text { BILECIK SEYH EDEBALI } \\
\text { UN IVERSITESI }\end{array}$ & & 2458-7575 (https://dergipark.org.tr/tr/pub/bseufbd) \\
\hline
\end{tabular}

edilmiş, ancak test sürecinde özellikle 2005-2010 yılları arasında modelin güneşlenme şiddeti değerlerini ölçülen değerden oldukça düşük tahmin ettiği belirlenmiştir.
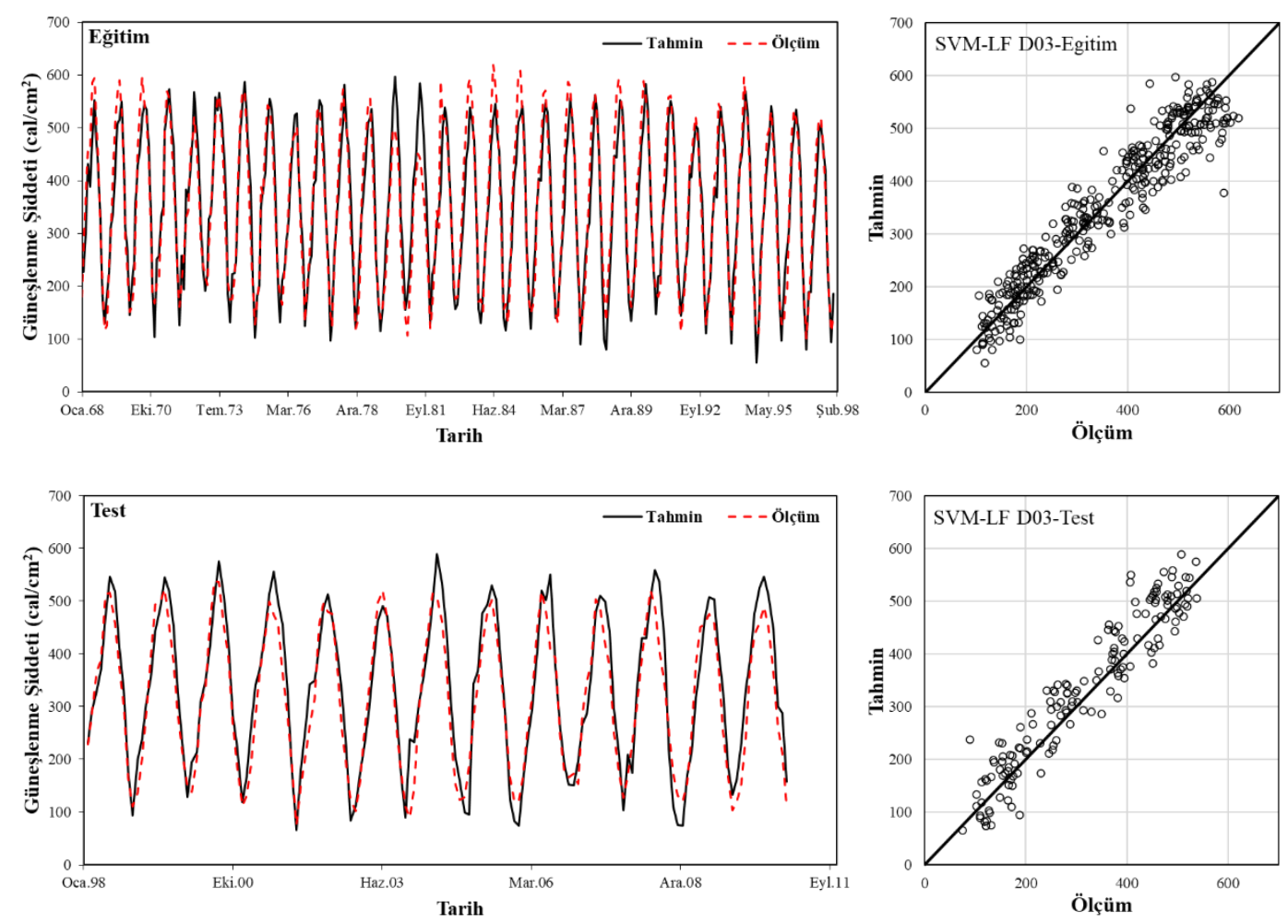

Şekil 4. $\mathrm{SVM}_{\mathrm{LF}}$ ile eğitim ve test sürecine ait D03durumunda tahmin edilen ve ölçülen güneşlenme şiddeti değerleri (Gaziantep istasyonu)
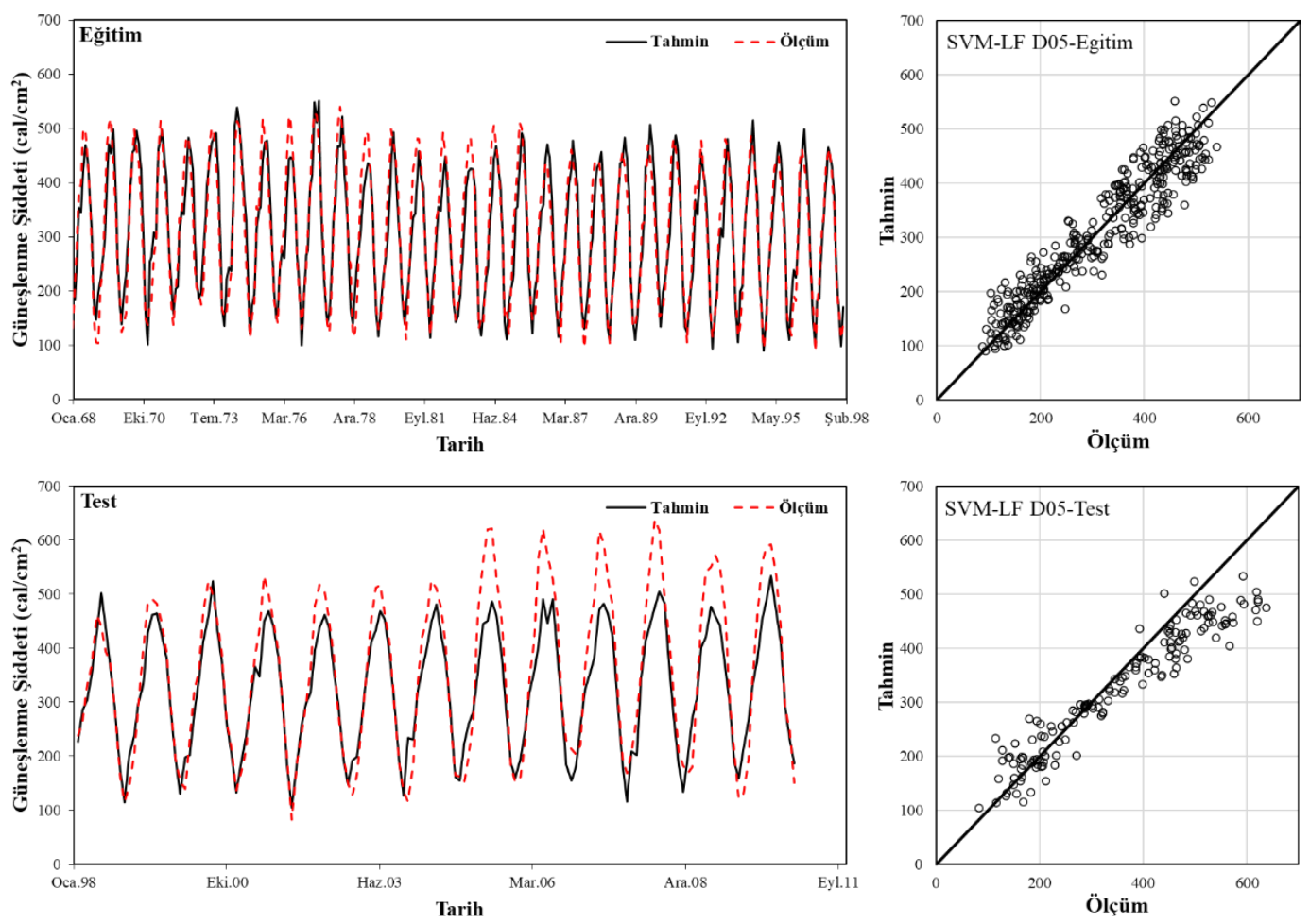

Şekil 5. SVM $\mathrm{LF}_{\mathrm{LF}}$ ile eğitim ve test sürecine ait D05 durumunda tahmin edilen ve ölçülen güneşlenme şiddeti değerleri (Adıyaman istasyonu) 


\begin{tabular}{|c|c|c|}
\hline & $\begin{array}{l}\text { BŞEÜ Fen Bilimleri Dergisi } \\
8(2), 753-769,2021\end{array}$ & $\begin{array}{r}\text { BSEU Journal of Science } \\
\text { https://doi.org/10.35193/bseufbd.904393 }\end{array}$ \\
\hline $\begin{array}{l}\text { BiLECIKSEYYHEDEBAL| } \\
\text { UNIVERSITESS }\end{array}$ & & 2458-7575 (https://dergipark.org.tr/tr/pub/bseufbd) \\
\hline
\end{tabular}

\section{B. Polinom Çekirdek Fonksiyonu (SVMPF) Sonuçlart}

Tablo 5'te, altı farklı girdi kombinasyonu ile Gaziantep ve Adıyaman istasyonlarında güneşlenme şiddetinin $\mathrm{SVM}_{\mathrm{PF}}$ ile tahmin edilmesiyle elde edilen sonuçlar verilmiştir. Tablo 5 'te yer alan Durum No kısmında, parantez içerisindeki değerler Tablo 2'de verilen $\gamma$ parametresidir. SVM $\mathrm{PF}_{\mathrm{PF}}$ 'de Tablo 2'deki çekirdek parametrelerinden $d$ değeri tüm modellerde $3, r$ değeri ise 1 olarak belirlenmiştir. Bu katsayılar Bayesian optimizasyon algoritması ile belirlenen optimum değerlerdir. Ayrıca, $\mathrm{SVM}_{\mathrm{PF}}$ için hazırlanmış Taylor diyagramları Şekil 6'da verilmiștir. Taylor diyagramları ve tablodan da görüldüğü üzere, her iki istasyonda da girdi parametresi olarak maksimum ve minimum sıcaklık parametresinin eklendiği D02-D04 modellerindeki başarının, diğer modellere göre az da olsa arttığı, ancak modeller arasında önemli bir fark olmadığı görülmektedir. Ayrıca, test sürecinde $\mathrm{SVM}_{\mathrm{PF}}$ yöntemi ile elde edilmiş olan $\mathrm{R}^{2}$ değerlerinin $0.9^{\prime}$ 'un üzerinde olduğu belirlenmiştir. $\mathrm{SVM}_{\mathrm{PF}}$ yöntemi ile test sürecinde elde edilmiş olan en başarılı modellerin ise, Gaziantep istasyonu için KOKH, OMYH ve NSE değerlerine göre D02, Adıyaman istasyonu için $\mathrm{R}^{2}$, KOKH ve OMYH değerlerine göre D04 olduğu görülmektedir. Adıyaman istasyonunda NSE değeri D01'de daha yüksek çıksa da D04 modeli diğer karşılaştırma

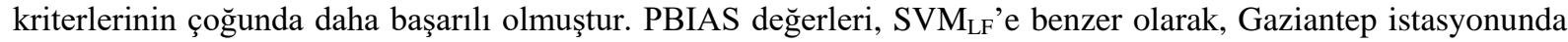
tahmin değerleri gerçek değerlerden büyük, Adıyaman istasyonunda ise küçük sonuçlar vermiştir. Bu durumlara ait eğitim ve test süreçlerindeki ölçülen ve tahmin edilen güneşlenme şiddeti değerlerinin zamansal dağılım ve saçılım grafikleri Gaziantep istasyonu için Şekil 7'de, Adıyaman istasyonu için ise Şekil 8'de verilmiştir. SVM yönteminde, Gaziantep istasyonu için eğitim ve test süreçlerinde tahmin edilen değerler ile ölçülen değerler arasındaki uyumun iyi olduğu, bunun yanında test sürecinde yüksek güneşlenme şiddeti değerlerini, ölçülen değerlerden az da olsa daha büyük tahmin ettiği belirlenmiştir. Adıyaman istasyonunda ise eğitim sürecinde uyumun iyi olduğu, ancak test sürecinde $\mathrm{SVM}_{\mathrm{LF}}$ yöntemine benzer bir şekilde 2005-2010 yılları arasındaki değerleri tahmin etmede başarılı olamadığı görülmüştür.

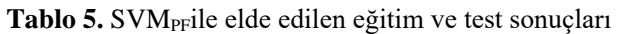

\begin{tabular}{|c|c|c|c|c|c|c|c|c|c|c|c|}
\hline \multirow{2}{*}{ İstasyon } & \multirow{2}{*}{$\begin{array}{c}\text { Durum } \\
\text { No }\end{array}$} & \multicolumn{5}{|c|}{ EĞİTìM } & \multicolumn{5}{|c|}{ TEST } \\
\hline & & $\mathbf{R}^{2}$ & KOKH & OMYH & NSE & PBIAS & $\mathbf{R}^{2}$ & КОКН & OMYH & NSE & PBIAS \\
\hline \multirow{6}{*}{ 혼 } & D01(9.80) & 0.9556 & 31.04 & 7.71 & 0.9448 & -0.3078 & 0.9575 & 49.57 & 15.11 & 0.8446 & -14.1580 \\
\hline & D02 (15.8) & 0.9734 & 23.95 & 4.49 & 0.9695 & 0.1005 & 0.9506 & 42.72 & 12.80 & 0.9113 & -9.8881 \\
\hline & D03 (25.3) & 0.9493 & 33.25 & 8.07 & 0.9178 & 0.7630 & 0.9501 & 44.68 & 14.72 & 0.8867 & -5.5344 \\
\hline & D04 (40.5) & 0.9621 & 28.58 & 5.94 & 0.9488 & 0.3690 & 0.9337 & 45.72 & 14.04 & 0.8689 & -9.5626 \\
\hline & D05 (76.9) & 0.9648 & 27.55 & 5.46 & 0.9545 & 0.0942 & 0.9355 & 45.98 & 14.29 & 0.8733 & -10.1252 \\
\hline & D06 (45.0) & 0.9627 & 28.34 & 6.14 & 0.9557 & 0.7321 & 0.9437 & 44.28 & 13.66 & 0.8846 & -8.7029 \\
\hline \multirow{6}{*}{ 总交充 } & D01 (8.38) & 0.9611 & 24.93 & 7.53 & 0.9568 & 0.00049 & 0.9111 & 62.41 & 13.05 & 0.8373 & 11.0942 \\
\hline & D02 (11.7) & 0.9711 & 21.47 & 5.70 & 0.9314 & 0.3495 & 0.9280 & 61.00 & 10.86 & 0.8261 & 9.9608 \\
\hline & D03 (86.2) & 0.9742 & 20.31 & 5.44 & 0.9488 & 0.6388 & 0.9297 & 59.91 & 10.62 & 0.7998 & 10.0513 \\
\hline & D04 (102) & 0.9752 & 19.91 & 4.90 & 0.9550 & 0.6312 & 0.9399 & 58.45 & 10.24 & 0.8107 & 10.2557 \\
\hline & D05 (50.9) & 0.9729 & 20.79 & 5.43 & 0.9452 & 0.4432 & 0.9390 & 61.33 & 11.68 & 0.8312 & 10.6680 \\
\hline & D06 (32.7) & 0.9773 & 19.07 & 4.71 & 0.9552 & 0.3705 & 0.9369 & 66.60 & 13.00 & 0.7924 & 13.2048 \\
\hline
\end{tabular}
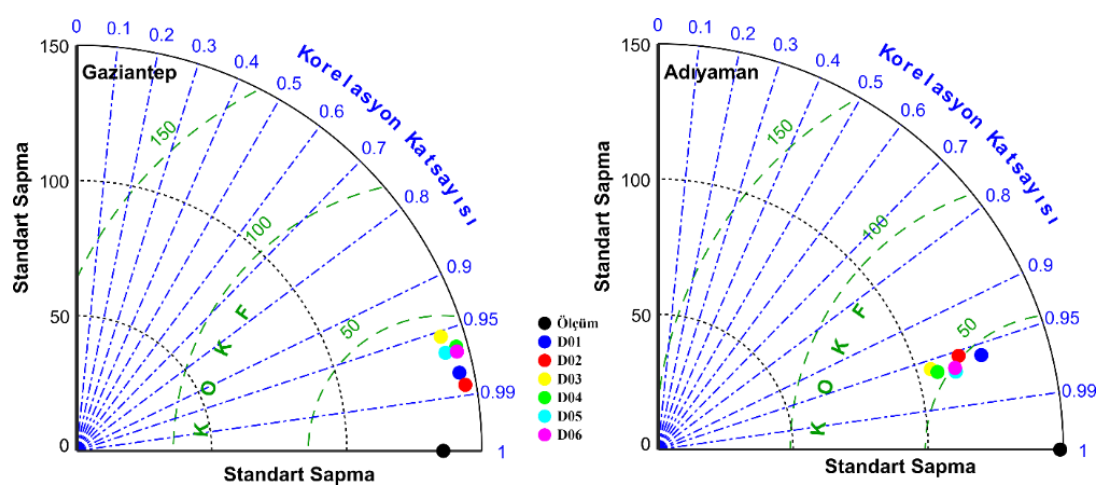

Şekil 6. $\mathrm{SVM}_{\mathrm{PF}}$ ile elde edilen Taylor diyagramları 


\begin{tabular}{|c|c|c|}
\hline & $\begin{array}{l}\text { BŞEÜ Fen Bilimleri Dergisi } \\
8(2), 753-769,2021\end{array}$ & $\begin{array}{r}\text { BSEU Journal of Science } \\
\text { https://doi.org/10.35193/bseufbd.904393 }\end{array}$ \\
\hline ERS I & & 2458-7575 (https://dergipark.org.tr/tr/pub/bseufbd) \\
\hline
\end{tabular}
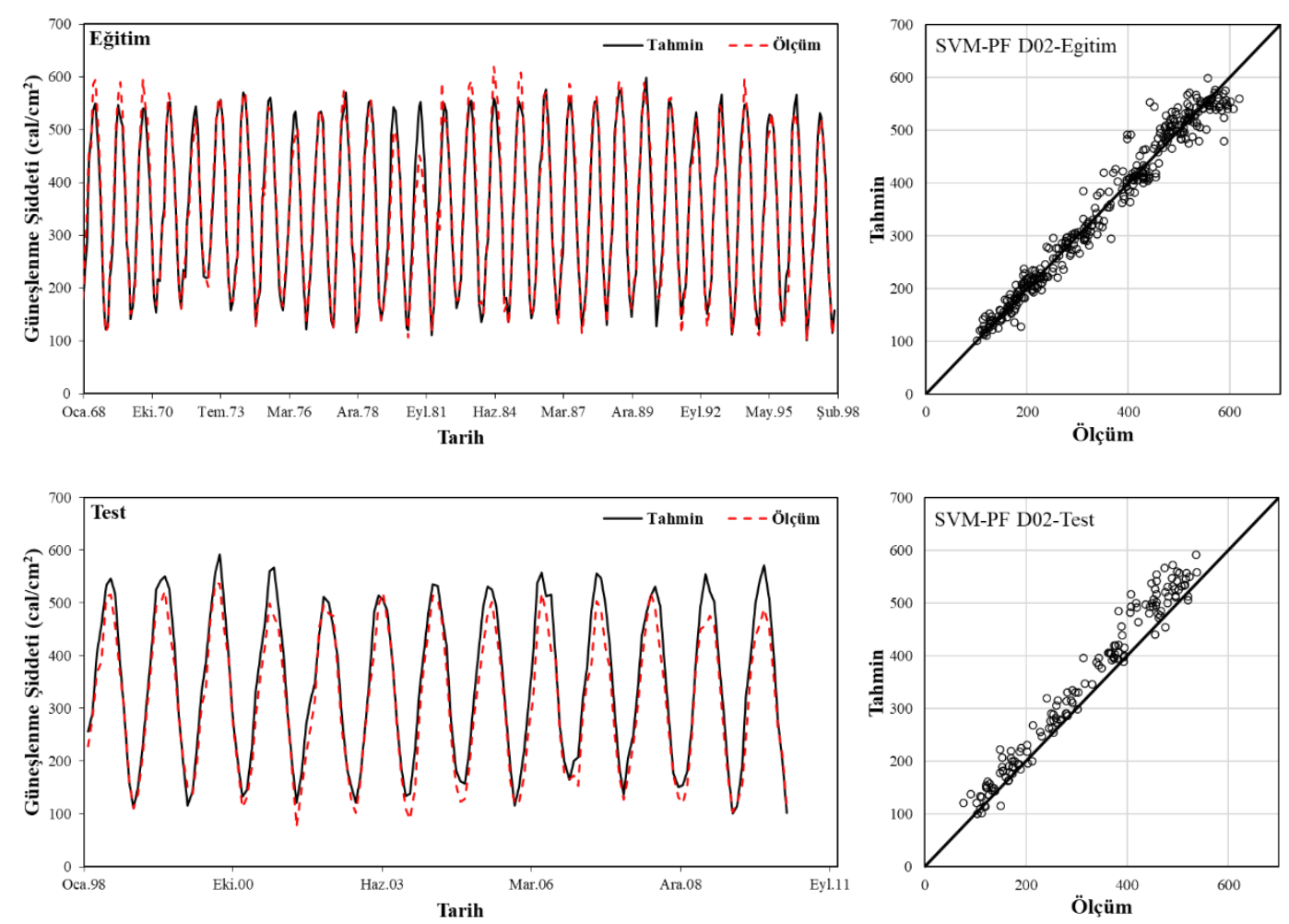

Şekil 7. SVM $M_{\mathrm{PF}}$ ile eğitim ve test sürecine ait D02 durumunda tahmin edilen ve ölçülen güneşlenme şiddeti değerleri (Gaziantep istasyonu)
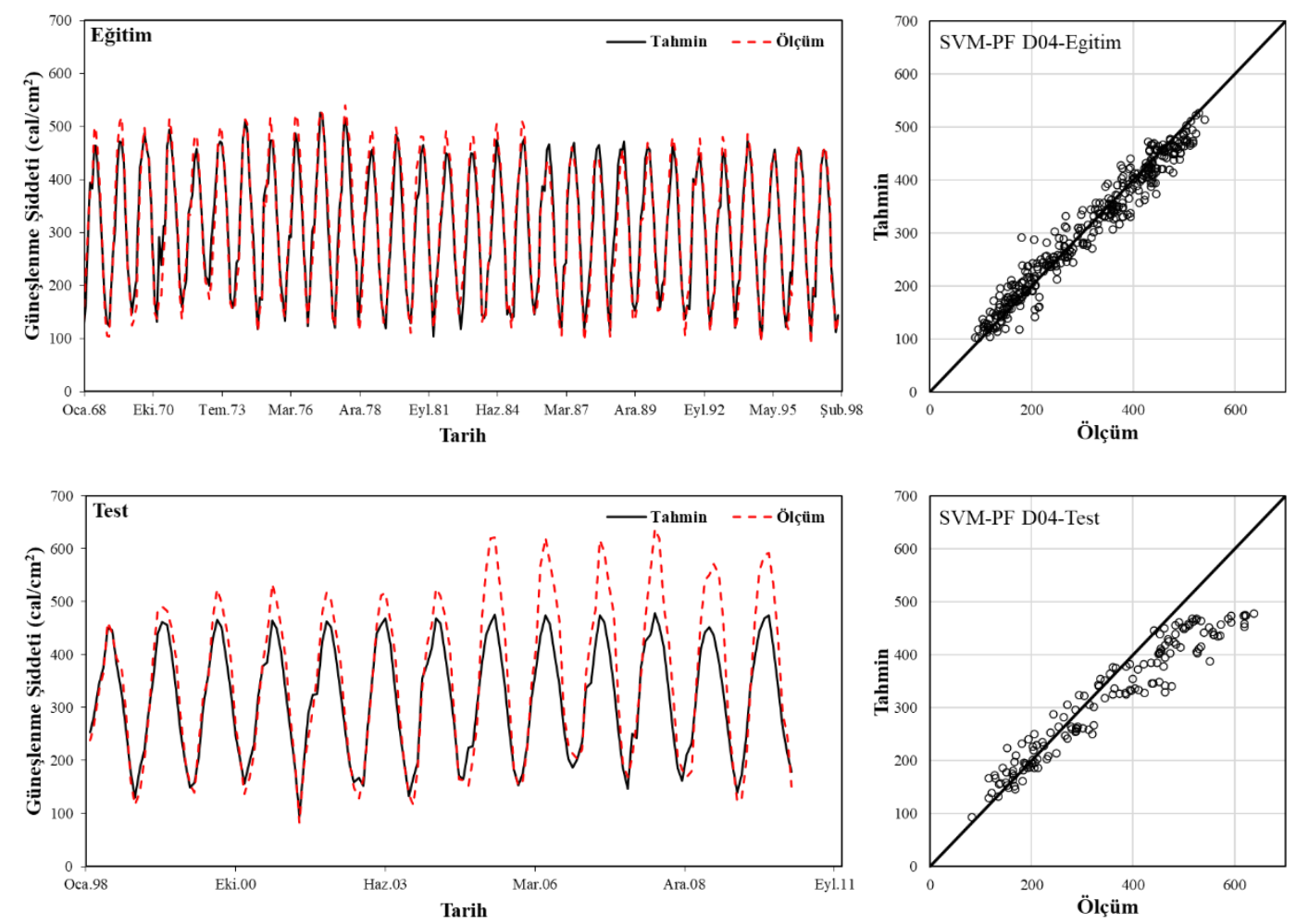

Şekil 8. $\mathrm{SVM}_{\mathrm{PF}}$ ile eğitim ve test sürecine ait D04 durumunda tahmin edilen ve ölçülen güneşlenme şiddeti değerleri (Adıyaman istasyonu) 


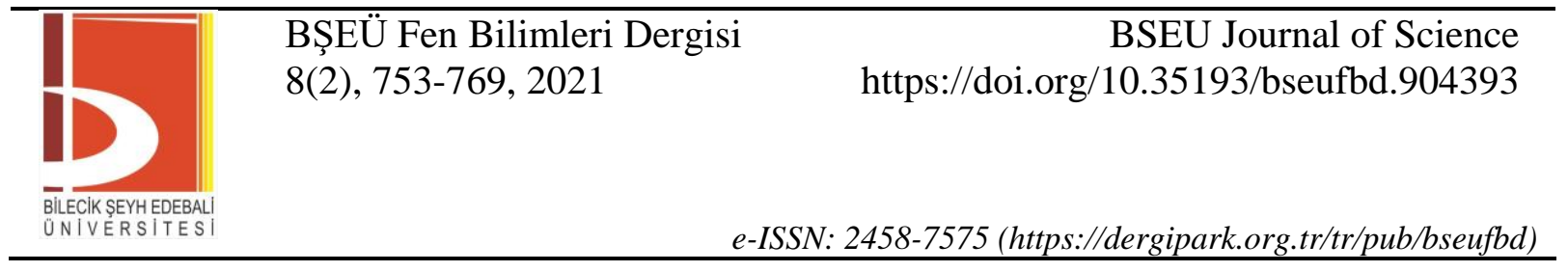

\section{Radyal Tabanlı Çekirdek Fonksiyonu (SVMRTF) Sonuçları}

Tablo 6'da, altı farklı girdi kombinasyonu için Gaziantep ve Adıyaman istasyonlarındaki güneşlenme şiddetinin $\mathrm{SVM}_{\mathrm{RTF}}$ yöntemi kullanılarak tahmin edilmesiyle elde edilen sonuçlar verilmiş̧tir.Tablo 6'da, Durum No kısmında parantez içerisindeki değerler, Tablo 2'de verilmiş olan ve Bayesian optimizasyon algoritması ile belirlenen optimum $\gamma$ 'dır. Ayrıca, SVM $_{\text {RTF }}$ için hazırlanmış Taylor diyagramları da Şekil 9'da verilmiştir. Tablodan, Gaziantep istasyonunda girdi parametresi olarak maksimum ve minimum sicaklık parametresinin eklendiği D02 modelinin başarısının diğer modellere göre daha yüksek olduğu belirlenirken, bu modele ait $\mathrm{R}^{2}$, KOKH, OMYH ve NSE değerleri sirasıyla $0.97198,40.43,11.81$ ve 0.9009 olmuştur.Adiyaman istasyonunda ise D05 modelinin $\mathrm{R}^{2}$ ve OMYH kriterlerine göre en başarılı model olduğu, KOKH ve NSE değerlerinin ise diğer modellere göre başarısının az da olsa düşük kaldığı görülmüştür. Başarı kriterlerinin çoğunda en uygun model bu nedenle D05 olarak değerlendirilmiştir. Test sürecinde $S_{V M} M_{R T F}$ yöntemi ile D05 modeline ait $R^{2}$ değerinin 0.9362 , KOKH değerinin 61.16, OMYH değerinin 12.62, NSE değerinin ise 0.8303 olduğu görülmüsstür. PBIAS değerinin, önceki iki yöntemde elde edilen sonuçlara benzer olduğu belirlenmiştir. Ancak, Taylor diyagramlarında korelasyon, KOKF ve standart sapma değerleri her iki istasyonda da birbirlerine yakın olmuştur. En iyi sonuçları veren durumlara ait eğitim ve test süreçlerindeki ölçülen ve tahmin edilen güneşlenme şiddeti değerlerinin zamansal dağılım ve saçılım grafikleri Gaziantep istasyonu için Şekil 10'da, Adıyaman istasyonu için ise Şekil 11 'de verilmiştir. Buna göre, bu fonksiyon ile belirlenen güneşlenme şiddeti değerleri diğer iki fonksiyon ile belirlenmiş değerlere göre nispeten benzer olmuş, ve Gaziantep istasyonundaki sonuçların ölçülen değerler ile uyumlu olduğu, Adıyaman istasyonunda ise test sürecinde 2005-2010 yılları arasında tahmin edilen değerler ile ölçülen değerler arasında önemli derecede bir fark olduğu görülmüş̧ür.

Tablo 6. $\mathrm{SVM}_{\mathrm{RTF}}$ ile elde edilen eğitim ve test sonuçları

\begin{tabular}{|c|c|c|c|c|c|c|c|c|c|c|c|}
\hline \multirow{2}{*}{ İstasyon } & \multirow{2}{*}{$\begin{array}{c}\text { Durum } \\
\text { No }\end{array}$} & \multicolumn{5}{|c|}{ EĞİTIM } & \multicolumn{5}{|c|}{ TEST } \\
\hline & & $\mathbf{R}^{2}$ & КOKH & OMYH & NSE & PBIAS & $\mathbf{R}^{2}$ & КОKН & OMYH & NSE & PBIAS \\
\hline \multirow{5}{*}{ 혼 } & D01 (8.85) & 0.9539 & 31.66 & 8.04 & 0.9433 & 0.2783 & 0.96929 & 49.92 & 15.57 & 0.8435 & -14.1339 \\
\hline & D02 (5.08) & 0.9696 & 25.61 & 5.56 & 0.9733 & 0.1155 & 0.97198 & 40.43 & 11.81 & 0.9009 & -9.4124 \\
\hline & D03 (11.5) & 0.9184 & 42.06 & 11.11 & 0.9486 & 0.9161 & 0.91073 & 45.68 & 15.70 & 0.8917 & -10.2298 \\
\hline & D04 (24.3) & 0.9489 & 33.20 & 7.80 & 0.9620 & 0.0813 & 0.93015 & 49.15 & 15.16 & 0.8866 & -9.0541 \\
\hline & D05 (22.6) & 0.9549 & 31.28 & 7.50 & 0.9647 & 0.1122 & 0.93411 & 48.32 & 15.36 & 0.8853 & -9.3205 \\
\hline \multirow{5}{*}{ 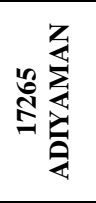 } & D02 (7.35) & 0.9318 & 33.04 & 10.34 & 0.9710 & 0.2798 & 0.9116 & 62.07 & 14.02 & 0.8321 & 10.7680 \\
\hline & D03 (12.9) & 0.9545 & 28.54 & 8.64 & 0.9741 & -0.2295 & 0.9203 & 66.62 & 13.44 & 0.8381 & 10.1958 \\
\hline & D04 (24.9) & 0.9586 & 26.75 & 7.87 & 0.9751 & -0.1253 & 0.9286 & 64.78 & 13.00 & 0.8458 & 10.2528 \\
\hline & D05 (35.1) & 0.9454 & 29.54 & 8.96 & 0.9728 & 0.0313 & 0.9362 & 61.16 & 12.62 & 0.8303 & 11.3873 \\
\hline & D06 (28.3) & 0.9553 & 26.70 & 7.91 & 0.9771 & -0.1652 & 0.9299 & 67.83 & 13.96 & 0.7999 & 13.3800 \\
\hline
\end{tabular}

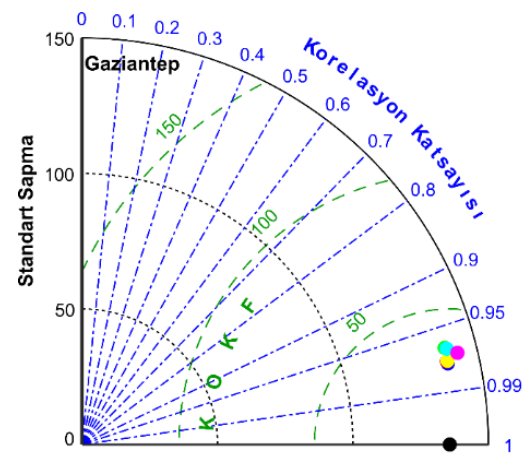

Standart Sapma

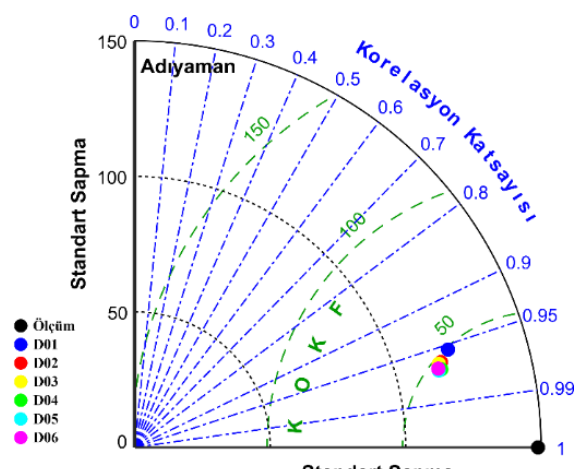

Standart Sapma

Şekil 9. SVM $\mathrm{STF}_{\text {RF }}$ ile elde edilen Taylor diyagramları 


\begin{tabular}{|c|c|c|}
\hline & $\begin{array}{l}\text { BŞEÜ Fen Bilimleri Dergisi } \\
8(2), 753-769,2021\end{array}$ & $\begin{array}{r}\text { BSEU Journal of Science } \\
\text { https://doi.org/10.35193/bseufbd.904393 }\end{array}$ \\
\hline ERS & & 2458-7575 (https://dergipark.org.tr/tr/pub/bseufbd) \\
\hline
\end{tabular}
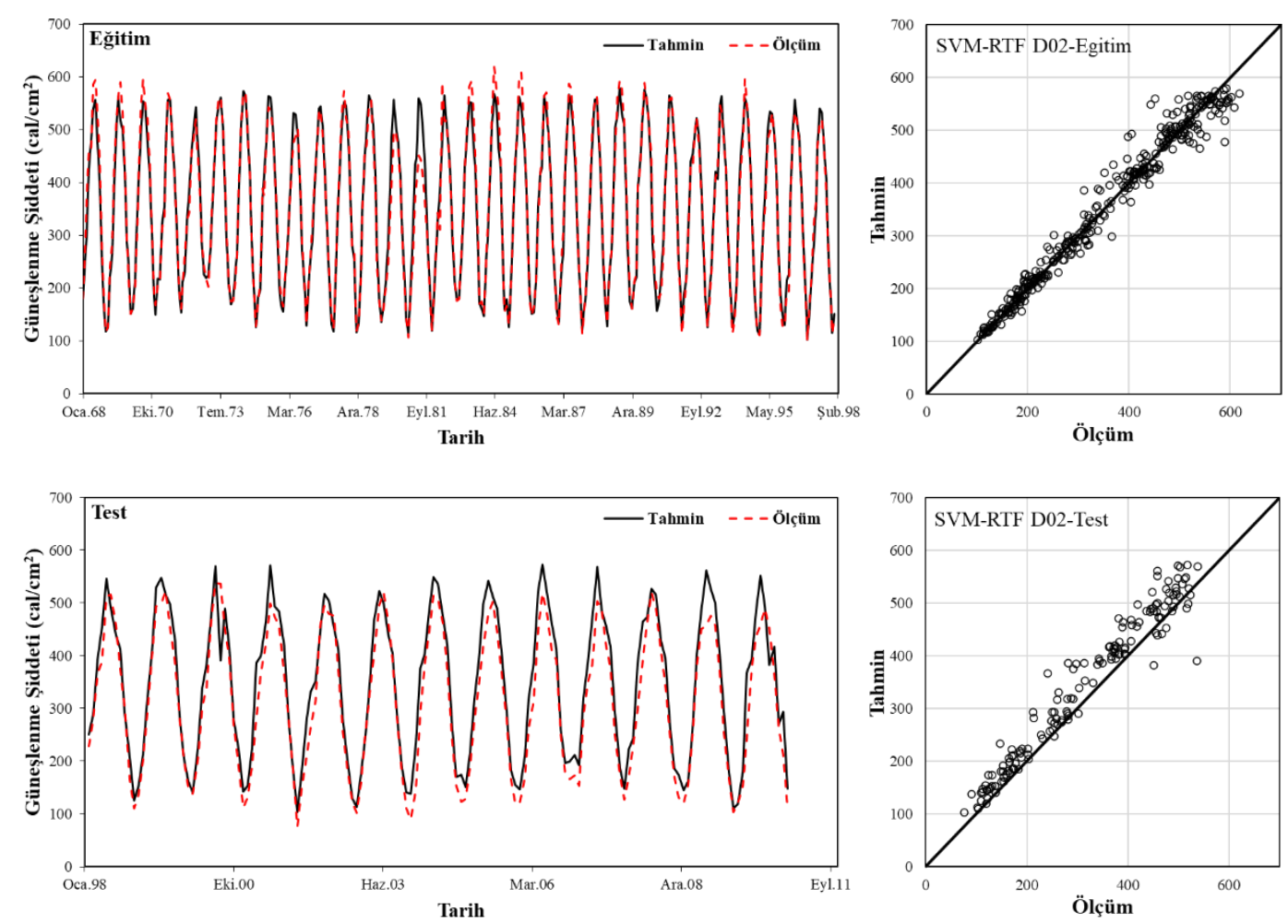

Şekil 10. SVM $\mathrm{RTF}_{\mathrm{R}}$ ile eğitim ve test sürecine ait D02 durumunda tahmin edilen ve ölçülen güneşlenme şiddeti değerleri (Gaziantep istasyonu)
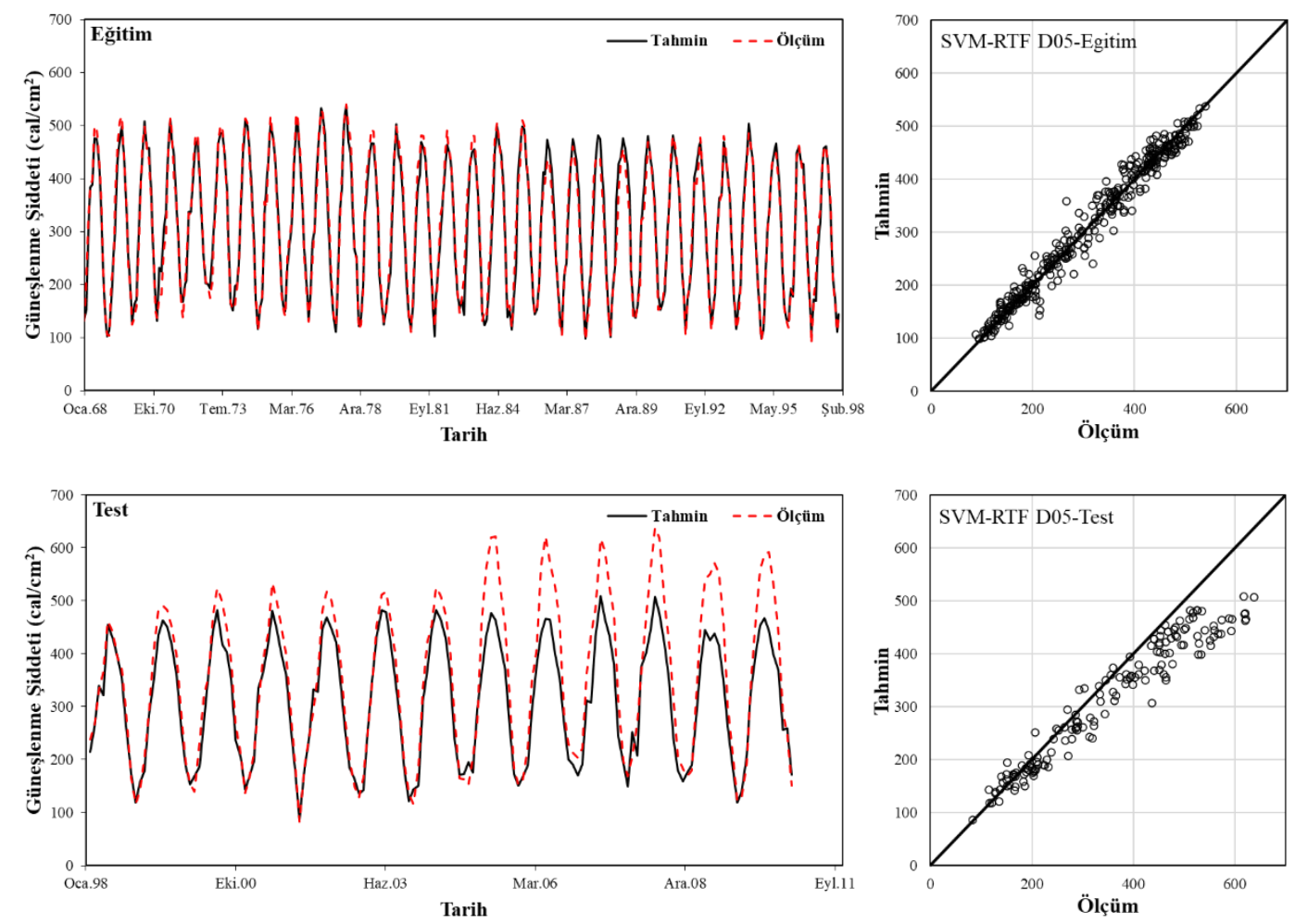

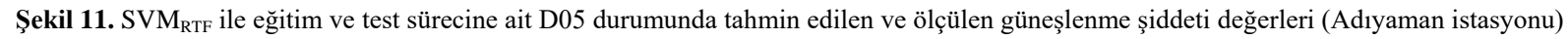




\section{SONUÇLAR}

Gaziantep ve Adıyaman istasyonlarına ait aylık ortalama günlük güneşlenme şiddeti değerlerinin farklı girdi parametreleri ile tahmin edilmesinde destek vektör makinelerine ait üç farklı çekirdek fonksiyonu kullanılarak tahmin edilmiştir. Altı girdi kombinasyonu için yapılan analizler neticesinde aşağıdaki sonuçlar elde edilmiştir.

- Gaziantep istasyonunda takvim ayı ve ortalama sıcaklığın yanında, minimum ve maksimum sıcaklığın eklendiği D02 durumunun, $S V M_{P F}$ ve $S V M_{R T F}$ 'de en uygun sonucu verdiği, iki yöntem arasında az bir farkla $S_{V M} M_{\text {RTF' }}$ 'nin en başarılı model olduğu belirlenmiştir. SVM $M_{\mathrm{LF}}$ yönteminde ise D02 durumunun üzerine ortalama basıncın eklendiği D03'ün başarılı olduğu, ancak diğer çekirdek fonksiyonlarına göre tahmin etme başarısının sınırlı olduğu görülmüştür.

- Adıyaman istasyonunda ise $\mathrm{SVM}_{\mathrm{PF}}$ 'de takvim ayı, ortalama sıcaklık, minimum sicaklık, maksimum sıcaklık, ortalama basınç ve nem parametrelerinin girdi olarak değerlendirildiği D04, SVM $\mathrm{LF}_{\mathrm{LF}}$ ve $\mathrm{SVM}_{\mathrm{RTF}}$ 'de ise D04 durumunun üzerine aylık açık gün sayısının da girdi parametresi olarak eklendiği D05 durumuen başarılı sonuçları vermiştir. Üç çekirdek fonksiyonu içerisinde Adıyaman istasyonunun güneşlenme şiddeti değerlerini tahmin etmede $\mathrm{SVM}_{\mathrm{PF}}$ 'nin en başarılı olduğu belirlenmiş̧tir. Ancak, ele alınan tüm çekirdek fonksiyonlarının 2005-2010 yılları arasındaki güneşlenme şiddeti değerlerini belirlemede nispeten başarısız olduğu görülmüştür.

- Her iki istasyon için en başarılı modellerde elde edilen $\mathrm{R}^{2}$ değerlerinin tüm yöntemlerde 0.9 değerinden büyük olduğu, OMYH değerinin ise 10-12 aralığında değiştiği belirlenmiştir. Ayrıca, değerlendirilen üç yöntem içinde en başarılı olarak belirlenen modellerin NSE değerlerinin 0.75 'ten yüksek olduğu görülmüştür.

- Ele alınan üç yöntemde elde edilen PBIAS değerlerine göre, Gaziantep istasyonunda tahmin edilen değerlerin gerçek değerlerden büyük (PBIAS $<0$ ), Adıyaman istasyonunda ise tahmin değerleri gerçek değerlerden küçük olmuştur (PBIAS $>0$ ).

- $\mathrm{SVM}_{\mathrm{LF}}, \mathrm{SVM}_{\mathrm{PF}}$ ve $\mathrm{SVM}_{\mathrm{RTF}}$ yöntemleri için güneşlenme şiddetini tahmin eden en başarılı modellerin arasındaki fark, OMYH değerine göre, Gaziantep istasyonunda \%3.66, Adiyaman istasyonunda ise $\% 3.03$ olmuştur.

$\mathrm{Bu}$ çalışmada, farklı iklim parametreleri girdi olarak kullanılarak, destek vektör makineleri yöntemlerindeki çekirdek fonksiyonlarının güneşlenme şiddetinin tahmin edilmesindeki başarısı değerlendirilmiştir. Çalışma sonucunda, sıcaklık parametresinin güneşlenme şiddetinin doğru tahmin etmede oldukça önemli bir parametre olduğu, polinom ve radyal çekirdek fonksiyonlarının lineer çekirdek fonksiyonuna göre nispeten dahabaşarılı sonuçlar verdiği belirlenmiştir. Bu çalışmanın devamında, destek vektör makineleri yöntemleriyle, ülkemizde farklı iklim özelliklerine sahip istasyonlarda girdi olarak,meteorolojik parametrelerinin yanı sıra, coğrafi özelliklerin de dikkate alınması suretiyle, yeni bir tahmin modelinin araştırılması önerilmektedir.

\section{KAYNAKLAR}

[1] Senkal, O. \& Kuleli, T. (2009). Estimation of solar radiation over Turkey using artificial neural network and satellite data. Applied Energy, 86(7-8), 1222-1228.

[2] Badescu, V. (2014). Modeling solar radiation at the earth's surface. Berlin: Springer. 1, 517.

[3] Droogers, P. \& Allen, R. G. (2002). Estimating Reference Evapotranspiration Under Inaccurate Data Conditions. Irrigation and Drainage Systems, 16(1), 33-45.

[4] Mellit, A. (2008). Artificial Intelligence technique for modelling and forecasting of solar radiation data: a review. International Journal of Artificial intelligence and soft computing, 1(1), 52-76.

[5] Besharat, F., Dehghan, A. A. \& Faghih, A. R. (2013). Empirical models for estimating global solar radiation: A review and case study. Renewable \& Sustainable Energy Reviews, 21, 798-821.

[6] Guermoui, M., Abdelaziz, R., Gairaa, K., Djemoui, L. \& Benkaciali, S. (2020). New temperature-based predicting model for global solar radiation using support vector regression. International Journal of Ambient Energy, 1-11.

[7] Mohsenzadeh Karimi, S., Kisi, O., Porrajabali, M., Rouhani-Nia, F. \& Shiri, J. (2020). Evaluation of the support vector machine, random forest and geo-statistical methodologies for predicting long-term air temperature. ISH Journal of Hydraulic Engineering, 26(4), 376-386.

[8] Fan, J., Wang, X., Wu, L., Zhou, H., Zhang, F., Yu, X., Lu, X. \& Xiang, Y. (2018). Comparison of Support Vector Machine and Extreme Gradient Boosting for predicting daily global solar radiation using temperature 
and precipitation in humid subtropical climates: A case study in China. Energy Conversion And Management, 164, 102-111.

[9] Shiri, J., Kisi, O., Landeras, G., Lopez, J. J., Nazemi, A. H. \& Stuyt, L. C. P. M. (2012). Daily reference evapotranspiration modeling by using genetic programming approach in the Basque Country (Northern Spain). Journal of Hydrology, 414, 302-316.

[10] Landeras, G., Lopez, J. J., Kisi, O. \& Shiri, J. (2012). Comparison of Gene Expression Programming with neuro-fuzzy and neural network computing techniques in estimating daily incoming solar radiation in the Basque Country (Northern Spain). Energy Conversion and Management, 62, 1-13.

[11] Güçlü, Y. S., Yeleğen, M. Ö., Dabanlı, İ. \& Şişman, E. (2014). Solar irradiation estimations and comparisons by ANFIS, Angström-Prescott and dependency models. Solar Energy, 109, 118-124.

[12] Güçlü, Y. S., Dabanlı, İ. \& Şişman, E. (2014). Short-and long-term solar radiation estimation method, In Progress in Exergy, Energy, and the Environment. 527-532.

[13] Citakoglu, H. (2015). Comparison of artificial intelligence techniques via empirical equations for prediction of solar radiation. Computers and Electronics in Agriculture, 118, 28-37.

[14] Güçlü, Y. S., Dabanlı, İ., Şişman, E. \& Şen, Z. (2015). HARmonic-LINear (HarLin) model for solar irradiation estimation. Renewable Energy, 81, 209-218.

[15] Belaid, S. \& Mellit, A. (2016). Prediction of daily and mean monthly global solar radiation using support vector machine in an arid climate. Energy Conversion and Management, 118, 105-118.

[16] Chiteka, K. \& Enweremadu, C. C. (2016). Prediction of global horizontal solar irradiance in Zimbabwe using artificial neural networks. Journal of Cleaner Production, 135, 701-711.

[17] Bakhashwain, J. M. (2016). Prediction of global solar radiation using support vector machines. International Journal of Green Energy, 13(14), 1467-1472.

[18] Hassan, G. E., Youssef, M. E., Mohamed, Z. E., Ali, M. A. \& Hanafy, A. A. (2016). New Temperature-based Models for Predicting Global Solar Radiation. Applied Energy, 179, 437-450.

[19] Laidi, M., Hanini, S., Rezrazi, A., Yaiche, M. R., El Hadj, A. A. \& Chellali, F. (2017). Supervised artificial neural network-based method for conversion of solar radiation data (case study: Algeria). Theoretical and Applied Climatology, 128(1-2), 439-451.

[20] Wang, L. C., Kisi, O., Zounemat-Kermani, M., Zhu, Z. M., Gong, W., Niu, Z. G., Liu, H. F. \& Liu, Z. J. (2017). Prediction of solar radiation in China using different adaptive neuro-fuzzy methods and M5 model tree. International Journal of Climatology, 37(3), 1141-1155.

[21] Hassan, M. A., Khalil, A., Kaseb, S. \& Kassem, M. A. (2017). Exploring the potential of tree-based ensemble methods in solar radiation modeling. Applied Energy, 203, 897-916.

[22] Basaran, K., Ozcift, A. \& Kilinc, D. (2019). A New Approach for Prediction of Solar Radiation with Using Ensemble Learning Algorithm. Arabian Journal for Science and Engineering, 44(8), 7159-7171.

[23] Gülşen, K., Sönmez, M. E. \& Karabaş, M. (2019). Gaziantep İlinde Güneş Enerjisi Potansiyelinin Analitik Hiyerarşi Süreci Yöntemi (AHP) İle Belirlenmesi. Coğrafya Dergisi, (39), 61-72.

[24] Alizamir, M., Kim, S., Kisi, O. \& Zounemat-Kermani, M. (2020). A comparative study of several machine learning based non-linear regression methods in estimating solar radiation: Case studies of the USA and Turkey regions. Energy, 197.

[25] Muhammed, O. (2020). Türkiye'nin Güneş Enerjisi Potansiyeli ve PV Uygulamalarının Yerel Ölçekte Değerlendirilmesi: Karabük İli Örneği. International Journal of Geography and Geography Education, (42), 482-503.

[26] Bilir, L. \& Yildirim, N. (2018). Modeling and performance analysis of a hybrid system for a residential application. Energy, 163, 555-569.

[27] GEPA. (2020). https://gepa.enerji.gov.tr/MyCalculator/ (Erişim tarihi: 26.03.2021)

[28] Vapnik, V. (2013). The nature of statistical learning theory. Springer science \& business media.

[29] Dibike, Y. B., Velickov, S., Solomatine, D. \& Abbott, M. B. (2001). Model induction with support vector machines: Introduction and applications. Journal of Computing in Civil Engineering, 15(3), 208-216.

[30] Bray, M. \& Han, D. (2004). Identification of support vector machines for runoff modelling. Journal of Hydroinformatics, 6(4), 265-280.

[31] Chen, H., Guo, J., Xiong, W., Guo, S. L. \& Xu, C. Y. (2010). Downscaling GCMs using the Smooth Support Vector Machine method to predict daily precipitation in the Hanjiang Basin. Advances in Atmospheric Sciences, 27(2), 274-284.

[32] Nieto, P. J. G., Torres, J. M., Fernandez, M. A. \& Galan, C. O. (2012). Support vector machines and neural networks used to evaluate paper manufactured using Eucalyptus globulus. Applied Mathematical Modelling, 36(12), 6137-6145. 
[33] Hosseini, S. M. \& Mahjouri, N. (2016). Integrating Support Vector Regression and a geomorphologic Artificial Neural Network for daily rainfall-runoff modeling. Applied Soft Computing, 38, 329-345.

[34] Khan, M. S. \& Coulibaly, P. (2006). Application of support vector machine in lake water level prediction. Journal of Hydrologic Engineering, 11(3), 199-205.

[35] Asefa, T., Kemblowski, M., Lall, U. \& Urroz, G. (2005). Support vector machines for nonlinear state space reconstruction: Application to the Great Salt Lake time series. Water Resources Research, 41(12).

[36] Khalil, A. F., McKee, M., Kemblowski, M., Asefa, T. \& Bastidas, L. (2006). Multiobjective analysis of chaotic dynamic systems with sparse learning machines. Advances in Water Resources, 29(1), 72-88.

[37] Ma, X., Zhang, Y. \& Wang, Y. (2015). Performance evaluation of kernel functions based on grid search for support vector regression. In 2015 IEEE 7th international conference on cybernetics and intelligent systems (CIS) and IEEE conference on robotics, automation and mechatronics (RAM). IEEE.

[38] Pelikan, M., Goldberg, D. E. \& Cantú-Paz, E. (2000). Hierarchical Problem Solving and the Bayesian Optimization Algorithm. In GECCO. 267-274.

[39] Moriasi, D. N., Gitau, M. W., Pai, N. \& Daggupati, P. (2015). Hydrologic and Water Quality Models: Performance Measures and Evaluation Criteria. Transactions of the ASABE, 58(6), 1763-1785.

[40] Taylor, K. E. (2001). Summarizing multiple aspects of model performance in a single diagram. Journal of Geophysical Research: Atmospheres, 106(D7), 7183-7192. 